$$
\begin{aligned}
& \text { NA,SA-TM-100109 } \\
& \text { Conf - 8706157 -.7 }
\end{aligned}
$$

NASA Technical Memorandum 100109 AIAA-87-1903

\title{
Nuclear Powered Mars Cargo Transport Mission Utilizing Advanced Ion Propulsion
}

Diane L. Galecki

Sverdrup Technology, Inc.

Lewis Research Center

Cleveland, Ohio

and

Michael J. Patterson

Lewis Research Center

Cleveland, Ohio

Prepared for the

23rd Joint Propulsion Conference

cosponsored by the AIAA, SAE, ASME, and ASEE

San Diego, California, June 29-July 2, 1987 


\section{DISCLAIMER}

This report was prepared as an account of work sponsored by an agency of the United States Government. Neither the United States Government nor any agency Thereof, nor any of their employees, makes any warranty, express or implied, or assumes any legal liability or responsibility for the accuracy, completeness, or usefulness of any information, apparatus, product, or process disclosed, or represents that its use would not infringe privately owned rights. Reference herein to any specific commercial product, process, or service by trade name, trademark, manufacturer, or otherwise does not necessarily constitute or imply its endorsement, recommendation, or favoring by the United States Government or any agency thereof. The views and opinions of authors expressed herein do not necessarily state or reflect those of the United States Government or any agency thereof. 


\section{DISCLAIMER}

Portions of this document may be illegible in electronic image products. Images are produced from the best available original document. 


\section{DISCLAIMER}

This report was prepared as an account of work sponsored by an agency of the United States Government. Neither the United States Government nor any agency thereof, nor any of their employees, makes any warranty, express or implied, or assumes any legal liability or responsibility for the accuracy, completeness, or usefulness of any information, apparatus, product, or process disclosed, or represents that its use would not infringe privately owned rights. Reference herein to any specific commercial product, process, or service by trade name, trademark, manufacturer, or otherwise does not necessarily constitute or imply its endorsement, recommendation, or favoring by the United States Government or any agency thereof. The views and opinions of authors expressed herein do not necessarily state or reflect those of the United States Government or any agency thereof. 


\title{
NUCLEAR POWERED MARS CARGO TRANSPORT MISSION
}

\section{UTILIZING ADVANCED ION PROPULSION}

\author{
Diane L. Galeck1 \\ Sverdrup Technology, Inc. \\ Lewis Research Center \\ Cleveland, Ohto 44135 \\ and \\ Michael J. Patterson \\ National Aeronautics and Space Administration \\ Lewis Research Center \\ Cleveland, Ohto 44135
}

\begin{abstract}
SUMMARY
Nuclear-powered ion propulsion technology was combined with detalled trajectory analysis to determine propulsion system and trajectory options for an unmanned cargo mission to Mars in support of manned Mars missions. A total of 96 mission scenarios were identified by combining two power levels, two prope 1lants, four values of specific impulse per propeliant, three starting altitudes, and two starting velocities. Sixty of these scenarios were selected for a detalled trajectory analysis; a complete propulsion system study was then conducted for 20 of these trajectories. Trip times ranged from 344 days for a xenon propulsion system operating at $300 \mathrm{~kW}$ total power and starting from lunar orbit with escape velocity, to 770 days for an argon propulsion system operating at $300 \mathrm{~kW}$ total power and starting from nuclear start orbit with circular velocity. Trip times for the $3 \mathrm{MW}$ cases studied ranged from 356 to 473 days. Payload masses ranged from 5700 to $12300 \mathrm{~kg}$ for the $300 \mathrm{~kW}$ power level, and from 72200 to $81500 \mathrm{~kg}$ for the $3 \mathrm{MW}$ power level.
\end{abstract}

\section{INTRODUCTION}

The National Commission on Space in its report "Pioneering the Space Frontier" (ref. 1) recommends a new look at electric propulsion for interplanetary misstons. Specifically, nuclear-powered ion propulsion is suggested as an attractive system for vehicles designed to travel from Earth to Mars and beyond. Unlike solar power, nuclear power offers the distinct advantage of constant power at any distance from the sun. Ion propulsion is especialiy advantageous for missions where high specific impulse (Isp) is important and trip time is less critical, such as unmanned cargo missions.

Many studies on low thrust interplanetary trajectories were performed in the 1960's and 1970's when electric propulsion was demanding much attention. Since the time of those studies, however, the ion technology base has become much more advanced. Recent mission studies using advanced ion systems discuss in detail the propulsion systems but use only greatiy simplified trajectory analysts (refs. 2 and 3 ). Also, recent work involving a $300 \mathrm{~kW}$ range nuclear power source indicates that this technology is also ready to be incorporated into future vehicle designs (ref. 4). The true merits of using an electric 
propulsion system for interplanetary trave1, therefore, are best seen when both the propulsion systems and the trajectory analysis are studied together.

This paper summarizes a study of nuclear-powered ion propulsion technology combined with detailed trajectory analyses to determine propulsion systems and trajectories for an unmanned cargo mission to Mars in support of manned Mars missions. Two power levels $(300 \mathrm{~kW}$ and $3 \mathrm{~mW})$ with corresponding initial masses (23 180 and $150000 \mathrm{~kg}$ ) were used to provide power for a $50-\mathrm{cm}$ ion thruster propulsion system using xenon or argon propellant. The ton technology parameters were then used as inputs to a low thrust interplanetary trajectory optimization computer code. Starting locations included nuclear start orbit (NSO), geosynchronous-equivalent-altitude orbit (GEO), and lunar orbit at both local circular and escape velocities (Vescape). Each trajectory was calculated over a range of specific impulse.

For the $300 \mathrm{~kW}$ power level, the trajectory beginning in NSO with circular velocity was studied most thoroughly because it was considered the nearest term mission application of nuclear electric propulsion. The $3 \mathrm{MW}$ power source and propulsion system were considered to be more advanced technology. By the time these technologies are avallable, a manned lunar base is expected to be operational, and, as postulated by the National Commission on Space, lunar orbit will be a logical starting point for interplanetary mis- sions. Therefore, for the $3 \mathrm{MW}$ power level, effort focused on the trajectory option which began in lunar orbit with circular velocity.

\section{NUCLEAR ELECTRIC PROPULSION}

This section describes the power and ion propulsion technologies selected for the Mars mission scenarios. Only nuclear power was considered for these mission applications due to total power requirement for delivery of substantial payload mass, and because the mission was an outbound planetary trajectory. making solar arrays less attractive as the power source. High specific impulse ion propulsion is a fuel efficient alternative to chemical propulsion for large delta $V$ missions. Ion thrusters are a relatively mature electric propulsion technology and provide the only near-term high (>3000 sec) specific impulse capability. They also have a potential growth to very high power levels.

\section{Power Technology}

The selection of the power systems for the Mars mission scenarios included two nuclear reactor power levels. The lower power scenarios used the SP-100 reactor mass and power speciffcations (ref. 4). These are a reactor mass of $7200 \mathrm{~kg}$ at an electrical power of $300 \mathrm{~kW}$. The higher power scenarios used a reactor mass of $30000 \mathrm{~kg}$ at $3 \mathrm{MW}$ electrical power (ref. 5).

\section{Ion Propulsion Technology}

Assessing the ion propulsion system required selection of the fon thruster technology (performance and operating conditions) and then determination of the propulsion system parameters (including system component masses and architecture). Thruster performance (specific impulse, thrust, power) can be projected for a variety of propellants by interpolation and extrapolation of thruster 
technology based on well known physical operating limits. These operating limits include the maximum electric field strength and maximum beam current density for the ion optics, as well as maximum power density due to thermal constraints. Experimental data has demonstrated (refs. 6 and 7 ) $30-\mathrm{cm}$ ion thruster operation with xenon propellant in excess of $10 \mathrm{~kW}$. Preliminary propulstion system analysis indicated that $30-\mathrm{cm}$ ion thrusters with xenon propellant at the low power case ( $300 \mathrm{~kW})$ may require an excessive number of thrusters to process this power. The number of thrusters is reduced somewhat by operating with a lower atomic weight propellant such as argon with a consequent increase in specific impulse, or by increasing the thruster diameter.

By increasing the thruster diameter, the power per thruster can be increased and the number of thrusters can be decreased. Prior research involving thruster designs beyond the $30-\mathrm{cm}$ diameter include both experimental efforts with $50-\mathrm{cm}$ and $1.5-\mathrm{m}$ diameter discharge chambers (refs. 8 and 9 ) and conceptual design studies of $50-\mathrm{cm}$ ion thrusters (refs. 10 to 12). In the intervening two decades since the initial experimental efforts with the $50-\mathrm{cm}$ mercury ion thruster were concluded, however, significant advances in ion thruster component technology have been made. These advances, including development of high emission current hollow cathodes, broad-beam high perveance ion optics, and magnetic-multipole discharge chamber plasma containment schemes, as well as the transition from mercury to inert gas propellants, should provide a performance capability greatly in excess of that previously demonstrated. With the straightforward nature of projecting $50-\mathrm{cm}$ thruster performance combined with the knowledge of an experimental effort now underway at NASA Lewis to develop and test $50-\mathrm{cm}$ ion thrusters at high power, the $50-\mathrm{cm}$ thruster was selected as the baseline design for this mission study.

The projected performance of $50-\mathrm{cm}$ diameter ion thrusters operating on xenon and argon propellants was calculated using the assumptions listed in appendix $A$. The performance numbers used in this analysis are shown in table I.

The ion propulsion system parameters were calculated using a methodology derived from Byers, et al. (ref. 13). This mass model defines the propulsion system into a thrust module and an interface module, as shown in table II. Table III lists the equations used in calculating the component masses of the thrust and interface modules. A set of propulsion system parameters were calculated for each value of ion thruster operating condition and each trajectory option. That is, after selecting a thruster operating condition (a total of 8:2 propellants at four values of Isp), 12 trajectories were calculated (six trajectory options at two values of total input power to the propulsion module) using these thruster numbers. Based on the calculated thrusting time and mission delta $V$ from the trajectory analyses, a system analysis was conducted to define the total propulsion system mass, including propellant. A payload delivery mass was then derived by subtracting total propulsion system mass, power source mass, and contingency $(1000 \mathrm{~kg}$ for $300 \mathrm{~kW}, 10000 \mathrm{~kg}$ for $3 \mathrm{MW}$ ) from the predefined value of inttial mass. No redundancy was included in the propulsion system with the exception of the reconfiguration units, controllers, and converters. Also, the mass of a guidance/navigation system was assumed to be a part of the spacecraft (payload) and hence was not included in the evaluation of the propulsion systems. 
The low thrust trajectory analysis was accomplished using the computer code NBODY (ref. 14), executed on a Cray XMP supercomputer. This code was developed and exercised extensively during the 60's and early $70^{\prime}$ 's when much work was being performed in the area of ion propulsion mission analysis. NBODY is a multi-purpose trajectory optimization program that includes either a highthrust escape or tangential-thrust spiral escape, an interplanetary trajectory with possible coast times, and either a high-thrust or spiral capture.

Detalled ephemeris data provide for a possible ten-body perturbation problem. optimization methods incorporated into the code provide for optimum thrust angle (angle between the thrust and velocity vectors), central travel angle (angle describing the arc traveled from initial to final locations), and on-off thrust times for a given trip time to insure maximum payload mass.

The initial mass was held constant for each power level. For the $300 \mathrm{~kW}$ power level the initial mass was restricted to one shuttle-equivalent payload to low Earth orbit (LEO). With the shuttle lift capability taken to be $27270 \mathrm{~kg}(60000 \mathrm{lbm})$, and allowing for 15 percent airborne support equipment (ASE) mass, the initial mass in LEO for the $300 \mathrm{~kW}$ power level was assumed to be $23180 \mathrm{~kg}$. The existence of an orbit transfer vehicle (OTV) to place the spacecraft in its initial starting altitude and velocity was assumed based on recent OTV mission models (ref. 15). For the $3 \mathrm{MW}$ power level an initial mass was obtained by adding the power source mass $(30000 \mathrm{~kg}$ ) to an estimated maxtmum propulsion system wet mass plus contingency plus an estimate for a sizable payload. This inftial mass in orbit for the $3 \mathrm{MW}$ power level was assumed to be $150000 \mathrm{~kg}$. The trajectory analysis was then performed with three different initial altitudes with two different initial velocities for a total of six trajectory options.

\section{Geocentric Phase}

The geocentric phase of the trajectory began at the initial altitude and continued until the spacecraft reached the edge of the earth's sphere of influence, taken to be at a radius of $925000 \mathrm{~km}$ from the center of the earth (145 earth radii). During this phase the Earth was the center of the system with the sun acting as a perturbing body. Table IV summarizes the six different initial conditions used in the study. Three starting altitudes were used: nuclear start orbit at an altitude of $800 \mathrm{~km}$; a geosynchronous-equivalent altitude of approximately $35700 \mathrm{~km}$; and a lunar orbit at an altitude of approximately $378000 \mathrm{~km}$. The spacecraft started in the ecliptic plane in all cases. At each of these starting altitudes two different initial velocities were used. The first was local circular velocity which then used a two-body tangentialthrust spiral escape. The second was local escape velocity which eliminated the need for a time consuming sptral. Thts escape velocity was assumed to be imparted to the spacecraft either by the orbit transfer vehicle which delivered the spacecraft to its starting point, or by a small chemical booster stage. It should be noted that while the difference between circular and escape velocittes at $N S O$ is $3100 \mathrm{~m} / \mathrm{s}$, this reduces to $1300 \mathrm{~m} / \mathrm{s}$ at $G E O$ and only $420 \mathrm{~m} / \mathrm{s}$ at a lunar orbit. 


\section{Heliocentric Phase}

Once the spacecraft reached a radius of $925000 \mathrm{~km}$ (145 earth radil) from the center of the earth, the origin of the system switched from the earth to the sun, and the interplanetary trajectory began. During this phase the sun was the center of the system with the Earth acting as a perturbing body. With a desired trip time and central travel angle as inputs, the program optimized the thrust angle (angle between the velocity and thrust vectors), and engine on-off times in order to obtain a maximum payload mass.

\section{Aerocentric Phase}

Although the program contains options for high-thrust or spiral captures at the target planet, the arrival conditions were simplified in this study by not including Mars as a perturbing body. The target conditions were Mars' radius from the sun and orbital velocity with a path angle (angle between the local horizontal and velocity vector) of zero. With these conditions the spacecraft will rendezvous with Mars and eventually settle into a high orbit. Since Mars' gravity is only one-third that of the Earth's, and since the spacecraft would remain in a high orbit, the introduction of Mars as a perturbing body would cause only a minimal change to total payload mass and trip time.

Table $V$ summarizes the combination of the six trajectory options with the 16 propulsion systems for a total of 96 mission scenarios.

\section{RESULTS AND DISCUSSION}

\section{Nuclear Electric Propulsion Systems}

From the 96 mission scenarios identified, total propulsion system masses were calculated for 20, as indicated in tables $V$ and VI. These inciude: (1) system masses at $300 \mathrm{~kW}$ power level with two propellants, over the range of four values of specific impulse for each propellant for the NSO spiral trajectory option (a total of eight missions); (2) system masses at $300 \mathrm{~kW}$ power level with two propellants, at one Isp per propellant for the five remaining trajectory options (a total of ten missions); and (3) system masses at 3 MW power level with two propellants, at one ISp per propellant for the lunar spiral trajectory option (a total of two missions). The first set of cases those spiraling from NSO at $300 \mathrm{~kW}$ power level - probably represent the most near-term of missions, whereas the $3 \mathrm{MW}$ spiral missions from the moon are more far-term missions applicable after the establishment of a manned lunar base.

From the first set of cases (NSO spiral at $300 \mathrm{~kW}$ ), it is seen from tables VI(a) and (b) that a reduction in total propulsion system mass occurs with increasing values of thruster specific impulse. The reason is twofold. At higher values of Isp, less propellant is required to accomplish the mission. Also, higher values of Isp in this case equate to higher beam voltages, and consequently higher thruster input power. Therefore, to process a fixed power into the propulsion module requires fewer thrusters. For these cases, the total number of thrusters required goes from 7 down to 3 over the range of Isp. 
For the $3 \mathrm{MW}$ power leve1, a primary consideration was the number of thrusters required to process the power avallable. The number of thrusters for the xenon system ranged from 50 to 70, while for the argon system the number of thrusters ranged from 30 to 40 . Since it is desirable to minimize the number of thrusters to reduce overall propulsion system size and complexity, only one Isp was used for each propellant in the trajectory analyses and the propulsion system analyses of the 3 MW power cases. Thts Isp was 5294 sec for xenon and $9591 \mathrm{sec}$ for argon. These two values correspond to the highest power per thruster and therefore require the fewest thrusters. The number of thrusters could be further decreased by going to even larger dlameter chamber/ ion optics, or by achieving higher voltages across the ion optics at a fixed close-gap. These are technologies which require demonstration and should be considered a much higher risk than the $50 \mathrm{~cm} / 2500$ total voltage thrusters used as a baseline in this study. As seen in tables VI(c) and (d), the total propulsion system dry mass is approximately ten times more massive than that for the $300 \mathrm{~kW}$ cases.

For all the mission scenarios, the total thrusting time determined from the trajectory analyses ranged from $3360 \mathrm{hr}$ (140 days; lunar spiral with xenon propellant at $3 \mathrm{MW}$ ), to $16680 \mathrm{hr}$ (695 days; NSO spiral with argon propellant at $300 \mathrm{~kW})$. Although these values are close to the projected iffetime of $16000 \mathrm{hr}$ at $2.65 \mathrm{~kW}$ for $30-\mathrm{cm}$ ion thrusters with mercury propellant (ref. 16), lifetime at the higher power levels required for the missions studied needs to be demonstrated. This range of total thrusting time corresponds to $2.07 \times 107$ to $9.43 \times 107 \mathrm{~N}-\mathrm{sec}$ total impulse per thruster.

\section{Trajectory Options}

Each power/propulsion system combination (power level, propellant, Isp) was used as inputs for all six trajectory options over a range of trip times. Typically, the mass fraction (final mass/initial mass) increased dramatically with increasing trip time and then leveled off to a nearly constant mass fraction as shown in figure 1. The trip time selected as the optimum time for use in the propulsion system mass analysis was the value at the knee of the curve, or the minimum time which provided near maximum mass fraction. Table VII 11sts some of the mission parameters for the 20 missions for which a propulsion system mass analysis was performed.

Figure 2 shows a breakdown of the spacecraft masses for the NSO spiral trajectory option using xenon propellant at an Isp of $5294 \mathrm{sec}$ and a power level of $300 \mathrm{~kW}$. Although this mission scenario delivers a relatively small payload mass, it can be seen that the payload is still more than 30 percent of the total initial mass. The figure also illustrates that the mass of the power source is a major part of the initial mass, and any reduction in this power source mass would lead directly to an increase in payload. Finally, it is seen that the total propulsion system dry mass is a small percentage of the initial mass.

Table VIII details the trajectory for the case of the spiral from nuclear start orbit with xenon propellant at a power level of $300 \mathrm{~kW}$ and an Isp of $5294 \mathrm{sec}$. The top half of the table lists the varlation with time of radius, velocity, path angle (angle between the velocity vector and local horizontal), revolutions about the Earth, orbit eccentricity, and vehicle mass for the geocentric phase of the mission. Note that the last entry (at 216.34 days) has an 
eccentricity greater than one, which indicates that the spacecraft has reached escape velocity and is on a hyperbolic path. The second half of the table lists the same parameters except that the central travel angle about the sun replaces revolutions about the Earth. Figure 3 shows this mission pictorially in two parts. Figure $3(a)$ shows the last 42 days of the geocentric spiral phase. It should be noted that the flattening of the spiral over the last few points is an indication of the sun's gravitational influence becoming stronger than the Earth's influence. Figure 3(b) shows the heliocentric portion of the trajectory, including the relative locations of the Earth and Mars at the start of the spiral (E1 and M1), at the start of the hellocentric phase (E2 and M2), and at the arrival in Mars orbit (E3 and M3). The solid lines indicate full throttle phases, while the dashed lines indicate coast phases. Also shown are some of the optimum thrust vectors. It can be seen that the spiral from nuclear start orbit to escape velocity at the earth's sphere of influence takes 216 days, more than 40 percent of the total trip time of 510 days. The final mass delivered to a high Mars orbit is $7392 \mathrm{~kg}$.

In order to determine the effects of Isp on the mission, the case of the spiral from nuclear start orbit at the $300 \mathrm{~kW}$ power level was run over a range of specific impulses corresponding to a range of net-to-total voltage ratios. It can be seen from figure 4 that the maximum payload mass varies about 25 percent over the specific impulse range for xenon and about 10 percent over the specific impulse range for argon. For a less energetic mission such as the trajectory starting from lunar orbit with escape velocity, the maximum payload mass varies less than 5 percent over the specific impulse range for xenon and less than 4 percent over the specific impulse range for argon. This decreasing sensitivity to Isp is due to the small propellant requirements of high Isp systems. Only for the more energetic (high delta $V$ ) missions did the range of specific impulse studied have a significant effect on the payload mass. The other mission parameter that is influenced by Isp is the optimum trip time. Since thrust decreased with increasing Isp for fixed power, the optimum trip time increased with increasing Isp as shown in figure 5 . Therefore, while the payload mass for the xenon system increased by 25 percent over the Isp range, the trip time simultaneously increased by 10 percent, and the payload mass for the argon system increased by only 10 percent while the trip time increased 15 percent. This clearly indicates the trade-offs necessary between trip time and Isp for fixed power.

As mentioned earlier, the trajectory and propulsion system analyses for the $3 \mathrm{MW}$ cases used only one value of specific impulse in order to minimize the number of thrusters. A second basis for analyzing only the highest Isp for each case was the similarity to the low power trajectories in terms of energy requirements. Because of the initial mass of $150000 \mathrm{~kg}$ selected for the 3 MW power level, the optimum trip time and delta $V$ requirement was similar to those of the corresponding low power cases. With these parameters following the same trends, it was anticipated that changes in Isp will have the same effect for the high power level as that discussed for the low power level. Because the $3 \mathrm{MW}$ power level was considered to be more advanced technology, attention was focused on the trajectory option that began in lunar orbit. This was based on current studies, such as the National Commission on Space Report (ref. 1) and the Space 1995 study (ref. 17), which recommend a manned lunar base in the next century.

Figure 6 summarizes the optimum total trip times for the six trajectory options for the $300 \mathrm{~kW}$ power level and for the lunar orbit spiral for the $3 \mathrm{MW}$ 
power leve1. Each bar is divided to show the thrusting and coasting phases. The total trip time varies less than 9 percent for the three trajectory options that began with local escape velocity. This should be expected since giving the spacecraft an initial escape velocity has the effect of removing the Earth's gravitational influence and relegating the earth to a perturbing body for the entire trajectory. In this case, the difference between NSO, GEO, and lunar orbit is small when compared to the distance between the Earth and the sun. The optimum trip times for the spiral cases, however, vary about 30 percent for the xenon cases and almost 70 percent for the argon cases. This is a significant difference which makes the advantage of a lunar base obvious when trip time becomes important. It should be noted from figure $6(b)$ that the maximum trip time is 770 days for the case of the spiral from NSO using argon propellant at the $300 \mathrm{~kW}$ power level. Although this is silightly more than 2 years, it is reasonable for an unmanned sample return, a robotic survey mission, or an unmanned payload delivery in support of a manned Mars mission. The minimum trip time is obtained for the trajectory options that began with escape velocity using xenon propellant. For these cases, the trip time is as low as 344 days.

Figure 7 shows payload mass for the six trajectory options for the $300 \mathrm{~kW}$ power level and for the lunar orbit spiral for the $3 \mathrm{MW}$ power leve1. Again it can be seen that for the three trajectory options that began with local escape velocity the payload mass is relatively constant. The same arguments used above to explain constant total trip time also apply here to payload mass. Since the Earth's gravity well is already conquered at the start of the mission, the difference in total delta $V$ required to reach Mars' orbit is small. All of the payloads for the $300 \mathrm{~kW}$ power level missions range from 7400 to $10700 \mathrm{~kg}$ for the xenon system, as shown in figure $7(\mathrm{a})$. and from 10200 to $12300 \mathrm{~kg}$ for the argon system, as shown in figure $7(\mathrm{~b})$. This is a sufficient payload capability to accomplish a sample return mission with an estimated required payload (return propellant included) in orbit of $6600 \mathrm{~kg}$, or a robotic survey mission with an estimated required payload in orbit of $4000 \mathrm{~kg}$ (ref. 18). Both the sample return and robotic survey are missions likely to occur in the initial phases of manned Mars missions. The payload mass for the case of the spiral from lunar orbit for the $3 \mathrm{MW}$ power level was $72200 \mathrm{~kg}$ for xenon and $81500 \mathrm{~kg}$ for argon. This mission scenario could be used to accomplish the delivery of a combination of a habitat or a power unit estimated at $22500 \mathrm{~kg}$, and heavy machinery, such as an earthmover or crane, estimated at $35000 \mathrm{~kg}$ (ref. 18). These payloads are typical of delivery missions that will be required in final preparation and continued support of manned Mars missions.

\section{CONCLUDING REMARKS}

A study was performed that combined nuclear-powered ion propulsion technology with detalled trajectory analysis to determine the propulsion system and trajectory options for an unmanned cargo mission to Mars in support of manned Mars missions. Two power levels ( $300 \mathrm{~kW}$ and $3 \mathrm{MW})$ were combined with two propellants (xenon and argon) at four values of specific impulse per propellant to provide a total of 16 possible propulsion systems. These were used as inputs to six trajectory options (starting positions of nuclear start orbit, geosynchronous-equivalent orbit, and lunar orbit with either local circular or local escape velocities) for a total of $96 \mathrm{mission}$ scenarlos. This number was reduced to 60 trajectory analyses and 20 trajectory and propulsion system analyses due to technology constraints and mission similarities. 
Increasing the Isp increased the payload mass delivered to Mars' orbit. This increase in payload mass was most significant (10 to 25 percent) for the more energetic (higher delta $V$ ) missions such as the spiral from nuclear start orbit. For the less energetic misstons such as the trajectory starting in lunar orbit with escape velocity, the payload mass increased less than 4 percent over the range of specific impulse studied.

Because fixed power was delivered to the propulsion module, the total thrust generated by the ion propulsion system decreased with increasing specific impulse. Due to this decrease in thrust, the propulsion module needed to operate for longer periods of time. These increased thrusting times partly negated the reduction in propellant mass requirement achieved by higher values of specific impulse. The lower thrust also resulted in longer total mission times. Consequently, a trade-off exists between ISP, total trip time, and payload mass delivered to Mars' orbit.

A mass breakdown showed that the power source is a significant percentage of the initial mass, and reductions in this would directly increase payload mass. Also, the dry mass of the propulsion system is not a significant portion of the initial mass.

Total trip times for the $300 \mathrm{~kW}$ power level ranged fram 344 days for a xenon propulsion system beginning from lunar orbit with escape velocity, to 770 days for an argon propulsion system beginning from nuclear start orbit with circular velocity. Total trip times for the $3 \mathrm{MW}$ power level ranged from 356 to 413 days. For the missions starting at local circular velocity, the time of the geocentric escape spiral was as much as 40 percent of the total mission time (starting from nuclear start orbit). For a given trajectory option (starting altitude and velocity), the total mission time was always longer when using argon propellant.

Payload masses ranged from 5700 to $12300 \mathrm{~kg}$ for the $300 \mathrm{~kW}$ power level, and 72200 to $81500 \mathrm{~kg}$ for the $3 \mathrm{MW}$ power level. For a given trajectory option, payload mass was always larger when using argon propellant.

The most significant result of the study was the determination of payload mass delivered to Mars' orbit. Any of the low power missions can deliver payloads that will be required of a manned Mars bulldup. Examples of these payloads would be a sample return mission or robotic survey mission. The high power cases studied have the capability of delivering a habitat module, power unit, or heavy machinery, or a combination of this equipment. A nuclearpowered ton propelled vehicle can play a vital role in mankind's first step into the solar system by accomplishing all unmanned missions presently envisioned in support of manned Mars exploration. 
Appendix A

The assumptions used in calculating projected $50-\mathrm{cm}$ ion thruster performance include:

(1) The beam current was derived from an empirical equation which predicts the performance of $30-\mathrm{cm}$ ion optics (ref. 19). This derived expression is given by

$$
J b=A \times 5.3 E-5 \times\left(V_{T}\right)^{2.2 /(M) \cdot 5}
$$

where $A$ is the effective beam area (for $50-\mathrm{cm}$ diameter), $M$ is the propellant a.m.u., and $V_{T}$ is the total accelerating voltage. Equation (1) represents 75 percent of the maximum beam current capability (for operating margin) attained experimentally;

(2) The total accelerating voltage used across the ion optics was $2500 \mathrm{~V}$, which is approximately 83 percent of the maximum voltage capability achieved with $30-\mathrm{cm}$ ion optics at a grid gap of $0.6 \mathrm{~mm}$;

(3) The total thrust loss due to beam divergence 10.98 , neglecting dependence on R-ratio) plus multiply-charged lons (0.969) was 0.95 ;

(4) Two-grid ion optics were assumed, with an effective range of net-tototal accelerating voltage $(R)$ of 0.55 to 0.90 ;

(5) A fixed power loss per thruster of $0.040 \mathrm{kw}$ was used;

(6) An ion beam production cost of $150 \mathrm{~W} / \mathrm{A}$ was used; and

(7) The discharge chamber propellant utilization efficiency was 0.95 , with a neutralizer flow rate of 0.1 A equivalent.

Four values of specific impulse were selected for the two propellants, corresponding to $R$ values of $0.55,0.70,0.80$, and 0.90 . At the thruster input powers associated with these $R$ values, the number of thrusters required to process the $276 \mathrm{~kW}(300 \mathrm{~kW}$ reactor power times an average total power processor unit (ppu) efficiency of 0.92 ) were not integral. Consequentiy, the power per thruster was reduced in each case by decreasing the beam current from the value calculated from equation (1) to an input power level per thruster which would provide for an integral number of thrusters. This was done while maintaining a constant beam voltage (to fix the specific impulse). 


\section{REFERENCES}

1. Pioneering the Space Frontier, Report of the National Commission on Space, Bantam Books, New York, 1986.

2. Coomes, E.P., Cuta, J.M., Webb, B.J., King, D.Q., Patterson, M.J., and Berkopec, F., "Pegasus: A Multi-Megawatt Nuclear Electric Propulsion System," Manned Mars Mission, Working Group Papers, M.B. Duke and P.W. Keaton, eds., NASA TM-89321-VOL-2, 1986, Section 5, pp. 769-786.

3. Bents, D., Patterson, M.J., Berkopec, F., Myers, I., and Pres ler, A., "Power System Technologies for the Manned Mars Mission," Manned Mars Mission, Working Group Papers, M.B. Duke and P.W. Keaton, eds., NASA TM-89321-VOL-2, 1986, Section 5, pp. 797-814.

4. Hardy, T.L., Rawlin, V.K., and Patterson, M.J., "Electric Propulsion Options for the SP-100 Reference Mission," NASA TM-88918, 1987.

5. Bloomfield, H.S., Private Communication, NASA Lewis Research Center, Cleveland, $\mathrm{OH}$, May 1987.

6. Patterson, M.J., "Performance Characteristics of Ring-Cusp Thrusters with Xenon Propellant," AIAA Paper 86-1392, June 1986. (NASA TM-87338).

7. Rawlin, V.K. and Patterson, M.J., "High Power Ion Thruster Performance," Presented at the Fourth Space Nuclear Power Conference, Jan. 1987.

8. Reader, P.D., "Experimental Performance of a 50 Centimeter Diameter Electron-Bombardment Ion Rocket," AIAA Paper 64-689, Aug. 1964.

9. Nakanishi, S. and Pawlik, E.V., "Experimental Investigation of a 1.5-meter Diameter Kaufman Thrustor," AIAA Paper 67-725, Sept. 1967.

10. Poesche1, R.L. and Kami, S., "Analysis and Design of Ion Thrusters for Large Space Systems," NASA CR-165140, 1980.

11. James E.L., "Analysis and Design of Ion Thrusters for Large Space Systems," NASA CR-165160, 1980.

12. Martin, A.R. and Bond, A., "A Review and Assessment of the Performance of Advanced Ion Thrusters," IAF Paper 85-202, Oct. 1985.

13. Byers, D.C., Terdan, F.F., and Myers, I.T., "Primary Electric Propulsion for Future Space Missions," AIAA Paper 79-0881, May 1979. (NASA TM-79141).

14. Strack, W.C., "NBODY - A Multipurpose Trajectory Optimization Computer Program," NASA TN D-7543, 1974.

15. "OTV Mission Models, Revision 9," MSFC/PF20, June 27, 1986.

16. Rawlin, V.K. and Mantenieks, M.A., "Effect of Fac1lity Background Gases on Internal Erosion of the $30-\mathrm{cm} \mathrm{Hg}$ Ion Thruster, "AIAA Paper 78-665, Apr. 1978. 
17. Covault, C., "Moon Base Gaining Support as New U.S. Space Goal," Aviation Week and Space Technology, Vol. 126, No. 19, May 11, 1987, pp. 22-24.

18. "Impact of Lunar and Planetary Missions on the Space Station," REPT-84-85D, Eagle Engineering, Inc., Houston, TX, Nov. 1984. (NASA CR-171832).

19. Rawlin, V.K., "Operation of the J-Series Thruster Using Inert Gas," AIAA Paper 82-1929, Nov. 1982. (NASA TM-82977). 
TABLE I. - PROJECTED 50-cm ION THRUSTER PERFORMANCE

\begin{tabular}{|c|c|c|c|c|c|c|c|}
\hline $\begin{array}{c}\text { Beam } \\
\text { current, } \\
\text { A }\end{array}$ & $\underset{N}{T h r u s t,}$ & $\begin{array}{l}\text { Thruster } \\
\text { input power, } \\
\mathrm{kW}\end{array}$ & $\begin{array}{l}\text { Specific } \\
\text { impulse, } \\
\text { secb }\end{array}$ & $\begin{array}{l}\text { Thruster } \\
\text { efficiency }\end{array}$ & $\begin{array}{c}\text { Beam } \\
\text { voltage, } \\
\text { va }\end{array}$ & $\begin{array}{c}\text { Net-to } \\
\text { total } \\
\text { voltage } \\
\text { ratio }\end{array}$ & $\begin{array}{c}\text { Propellant } \\
\text { flowrate } \\
\mathrm{kg} / \mathrm{sec}^{\mathrm{b}}\end{array}$ \\
\hline \multicolumn{8}{|c|}{ Propellant $=$ Xenon } \\
\hline $\begin{array}{l}25.8 \\
24.2 \\
25.6 \\
23.0\end{array}$ & $\begin{array}{l}1.50 \\
1.59 \\
1.79 \\
1.71\end{array}$ & $\begin{array}{l}39.39 \\
46.02 \\
55.08 \\
55.24\end{array}$ & $\begin{array}{l}4138 \\
4669 \\
4991 \\
5294\end{array}$ & $\begin{array}{l}0.77 \\
0.79 \\
0.80 \\
0.80\end{array}$ & $\begin{array}{l}1375 \\
1750 \\
2000 \\
2250\end{array}$ & $\begin{array}{l}0.55 \\
0.70 \\
0.80 \\
0.90\end{array}$ & $\begin{array}{ll}3.51 & E-5 \\
3.29 & E-5 \\
3.48 & E-5 \\
3.13 & E-5\end{array}$ \\
\hline \multicolumn{8}{|c|}{ Propellant = Argon } \\
\hline $\begin{array}{l}45.2 \\
48.4 \\
42.7 \\
38.3\end{array}$ & $\begin{array}{l}1.45 \\
1.75 \\
1.65 \\
1.57\end{array}$ & $\begin{array}{l}68.97 \\
92.00 \\
91.85 \\
91.96\end{array}$ & $\begin{array}{l}7498 \\
8459 \\
9043 \\
9591\end{array}$ & $\begin{array}{l}0.77 \\
0.79 \\
0.80 \\
0.80\end{array}$ & $\begin{array}{l}1375 \\
1750 \\
2000 \\
2250\end{array}$ & $\begin{array}{l}0.55 \\
0.70 \\
0.80 \\
0.90\end{array}$ & $\begin{array}{ll}1.86 & E-5 \\
2.00 & E-5 \\
1.76 & E-5 \\
1.58 & E-5\end{array}$ \\
\hline
\end{tabular}

aThe screen grid voltage was used as an approximate value for the beam voltage.

bThese were used in the trajectory analysis as the values of exhaust velocity and spacecraft mass loss rate which produced useful thrust; precise thruster Isp, and total flow rates used in the calculation of total propellant mass, vary by less than 5 percent.

TABLE II. - PROPULSION SYSTEM MODEL DESCRIPTION

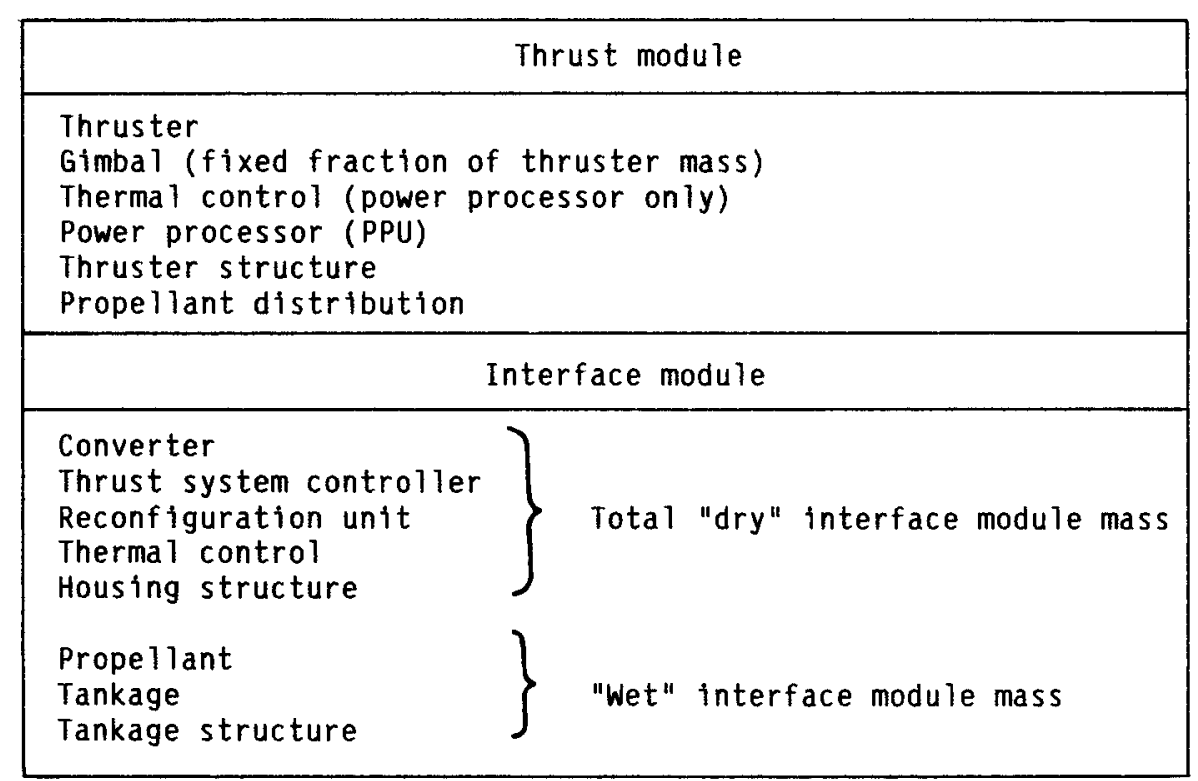


TABLE III. - SUMMARY OF MASSES AND EQUATIONSa

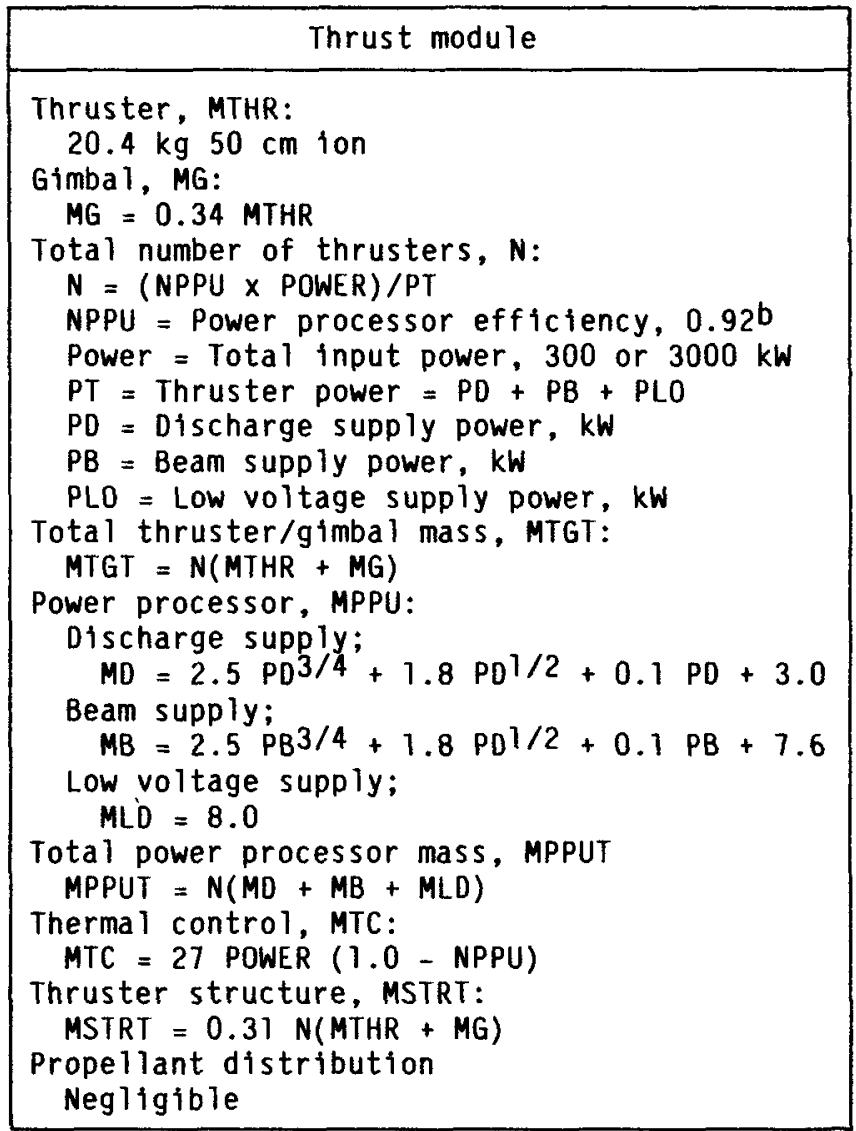

amasses from reference 13 .

bTotal PPU efficiency assumed to be constant over the range of specific impulse. 
TABLE III. - CONCLUDED

\begin{tabular}{|c|c|}
\hline \multicolumn{2}{|c|}{ Interface module } \\
\hline 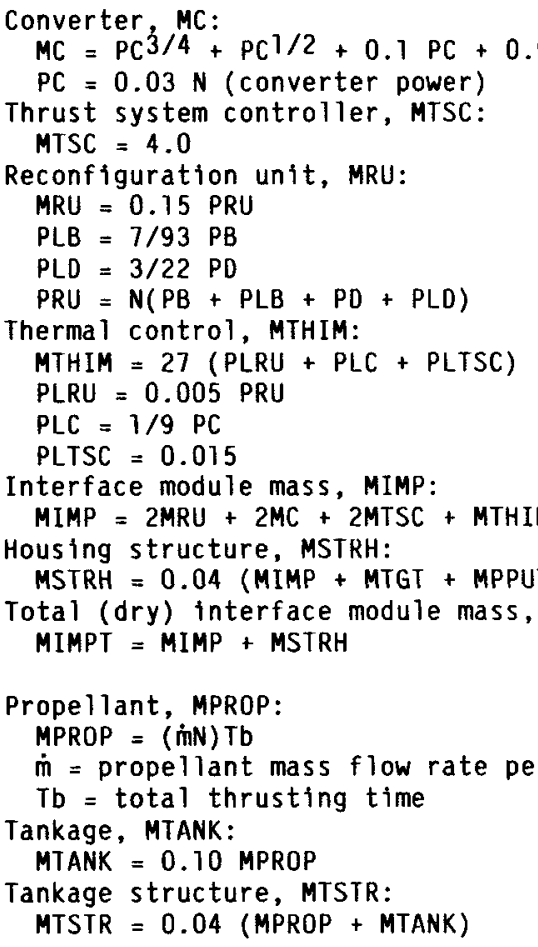 & $\begin{array}{l}\text { (reconfiguration unit dissipated power) } \\
\text { (converter dissipated power) } \\
\text { (controller dissipated power) } \\
\text { M } \\
\text { + MSTRT + MTC) } \\
\text { MIMPT: }\end{array}$ \\
\hline
\end{tabular}


TABLE IV. - INITIAL CONDITIONS

\begin{tabular}{|c|c|c|c|}
\hline $\begin{array}{c}\text { Trajectory } \\
\text { option }\end{array}$ & $\begin{array}{c}\text { Initial } \\
\text { altitude, } \\
\mathrm{km}\end{array}$ & $\begin{array}{c}\text { Inftial } \\
\text { velocity, } \\
\mathrm{m} / \mathrm{s}\end{array}$ & $\begin{array}{l}\text { Spiral } \\
\text { escape }\end{array}$ \\
\hline $\begin{array}{l}1 \\
2 \\
3 \\
4 \\
5 \\
6\end{array}$ & $\begin{array}{rll} & 800 & \text { (NSO) } \\
35 & 700 & \text { (GEO) } \\
378 & 000 & \text { (Lunar) } \\
800 & \text { (NSO) } \\
35 & 700 \text { (GEO) } \\
378 & 000 \text { (Lunar) }\end{array}$ & $\begin{array}{rl}10 & 538 \\
4 & 352 \\
1 & 438 \\
7 & 452 \\
3 & 077 \\
1 & 018\end{array}$ & $\begin{array}{l}\text { No } \\
\text { No } \\
\text { No } \\
\text { Yes } \\
\text { Yes } \\
\text { Yes }\end{array}$ \\
\hline
\end{tabular}

TABLE V. - MISSION SCENARIOS

[TA - Trajectory Analysis only. PSA - Propulsion System and Trajectory Analysis. * - Preliminary Analysis only.]

\begin{tabular}{|c|c|c|c|c|c|c|c|c|}
\hline & \multirow{2}{*}{\multicolumn{2}{|c|}{$\begin{array}{l}\text { Trajectory } \\
\text { options }\end{array}$}} & \multicolumn{3}{|c|}{ Vescape } & \multicolumn{3}{|c|}{ Spiral } \\
\hline $\begin{array}{l}\text { Propulsion } \\
\text { system } \\
\text { options }\end{array}$ & & & \multirow[t]{2}{*}{ NSO } & \multirow[t]{2}{*}{ GEO } & \multirow[t]{2}{*}{ Lunar } & \multirow[t]{2}{*}{ NSO } & \multirow[t]{2}{*}{ GEO } & \multirow[t]{2}{*}{ Lunar } \\
\hline $\begin{array}{c}\text { Total input } \\
\text { power, } \\
\text { kw }\end{array}$ & Propellant & $\begin{array}{l}\text { I sp, } \\
\text { sec }\end{array}$ & & & & & & \\
\hline 300 & $x e$ & $\begin{array}{l}4138 \\
4669 \\
4991 \\
5294 \\
\\
7498 \\
8459 \\
9043 \\
9591\end{array}$ & $\begin{array}{l}\text { PSA } \\
\text { PSA } \\
\text { PSA } \\
\text { PSA } \\
\\
\text { PSA } \\
\text { PSA } \\
\text { PSA } \\
\text { PSA }\end{array}$ & $\begin{array}{l}\text { TA } \\
\text { TA } \\
\text { TA } \\
\text { PSA } \\
\\
\text { TA } \\
\text { TA } \\
\text { TA } \\
\text { PSA }\end{array}$ & $\begin{array}{l}\text { TA } \\
\text { TA } \\
\text { TA } \\
\text { PSA } \\
\\
\text { TA } \\
\text { TA } \\
\text { TA } \\
\text { PSA }\end{array}$ & $\begin{array}{l}\text { TA } \\
\text { TA } \\
\text { TA } \\
\text { PSA } \\
\text { TA } \\
\text { TA } \\
\text { TA } \\
\text { PSA }\end{array}$ & $\begin{array}{l}\text { TA } \\
\text { TA } \\
\text { TA } \\
\text { PSA } \\
\\
\text { TA } \\
\text { TA } \\
\text { TA } \\
\text { PSA }\end{array}$ & $\begin{array}{l}\text { TA } \\
\text { TA } \\
\text { TA } \\
\text { PSA } \\
\text { TA } \\
\text { TA } \\
\text { TA } \\
\text { PSA }\end{array}$ \\
\hline 3000 & $\mathrm{Xe}$ & $\begin{array}{l}4138 \\
4669 \\
4991 \\
5294 \\
\\
7498 \\
8459 \\
9043 \\
9591\end{array}$ & $\begin{array}{r}\star \\
\star \\
\star \\
\text { TA } \\
\star \\
\star \\
\star \\
\text { TA }\end{array}$ & $\begin{array}{r}\star \\
\star \\
\star \\
\text { TA } \\
\star \\
\star \\
\star \\
\text { TA }\end{array}$ & $\begin{array}{r}\star \\
\star \\
\star \\
T A \\
\star \\
\star \\
\star \\
\text { TA }\end{array}$ & $\begin{array}{r}\star \\
\star \\
\star \\
\text { TA } \\
\star \\
\star \\
\star \\
\text { TA }\end{array}$ & $\begin{array}{r}\star \\
\star \\
\star \\
\text { TA } \\
\star \\
\star \\
\text { * } \\
\text { TA }\end{array}$ & $\begin{array}{c}\star \\
\star \\
\star \\
\text { PSA } \\
\star \\
\star \\
\text { * } \\
\text { PSA }\end{array}$ \\
\hline
\end{tabular}


TABLE VI. - ION PROPULSION SYSTEM COMPONENT MASSES

(a) Nuclear start orbit spiral, Xenon, $300 \mathrm{~kW}$

\begin{tabular}{|c|c|c|c|c|}
\hline Mission scenario & $\begin{array}{c}\text { NSO } \\
\text { spíral }\end{array}$ & $\begin{array}{c}\text { NSO } \\
\text { spiral }\end{array}$ & $\begin{array}{c}\text { NSO } \\
\text { spiral }\end{array}$ & $\begin{array}{l}\text { NSO } \\
\text { spiral }\end{array}$ \\
\hline $\begin{array}{l}\text { Propellant } \\
\text { Isp, sec } \\
\text { Total power, kw } \\
\text { Number of thrusters }\end{array}$ & $\begin{array}{r}\text { Xenon } \\
4138 \\
300 \\
7\end{array}$ & $\begin{array}{r}\text { Xenon } \\
4669 \\
300 \\
6\end{array}$ & $\begin{array}{r}\text { Xenon } \\
4991 \\
300 \\
5\end{array}$ & $\begin{array}{r}\text { Xenon } \\
5294 \\
300 \\
5\end{array}$ \\
\hline $\begin{array}{l}\text { Thruster/Gimbal, } \mathrm{kg} \\
\text { Thermal control, } \mathrm{kg} \\
\text { Power processor, } \mathrm{kg} \\
\text { Thruster structure, } \mathrm{kg} \\
\text { Total interface module (dry), } \mathrm{kg}\end{array}$ & $\begin{array}{r}191 \\
648 \\
560 \\
59 \\
206\end{array}$ & $\begin{array}{r}164 \\
648 \\
519 \\
51 \\
203\end{array}$ & $\begin{array}{r}137 \\
648 \\
476 \\
42 \\
199\end{array}$ & $\begin{array}{r}137 \\
648 \\
475 \\
42 \\
199\end{array}$ \\
\hline Total dry mass, $\mathrm{kg}$ & 1664 & 1585 & 1502 & 1501 \\
\hline $\begin{array}{l}\text { Propellant, } \mathrm{kg} \\
\text { Tankage, } \mathrm{kg} \\
\text { Tankage structure, } \mathrm{kg}\end{array}$ & $\begin{array}{r}6685 \\
669 \\
294\end{array}$ & $\begin{array}{r}5956 \\
596 \\
262\end{array}$ & $\begin{array}{r}5569 \\
557 \\
245\end{array}$ & $\begin{array}{r}5321 \\
532 \\
234\end{array}$ \\
\hline Total propulsion sys & 9312 & 8399 & 7873 & 7588 \\
\hline
\end{tabular}

(b) Nuclear start orbit spiral, Argon, $300 \mathrm{~kW}$

\begin{tabular}{|l|r|r|r|r|}
\hline Mission scenario & NSO & \multicolumn{1}{|c|}{$\begin{array}{c}\text { NSO } \\
\text { spiral }\end{array}$} & $\begin{array}{c}\text { NSO } \\
\text { spiral }\end{array}$ & $\begin{array}{r}\text { NSO } \\
\text { spiral }\end{array}$ \\
\hline Propellant & Argon & Argon & Argon & Argon \\
Isp, sec & 7498 & 8459 & 9043 & 9591 \\
Total power, kW & 300 & 300 & 300 & 300 \\
Number of thrusters & 4 & 3 & 3 & 3 \\
\hline Thruster/Gimbal, kg & 109 & 82 & 82 & 82 \\
Thermal control, kg & 648 & 648 & 648 & 648 \\
Power processor, kg kg & 441 & 332 & 388 & 386 \\
Thruster structure, $\mathrm{kg}$ & 34 & 25 & 25 & 25 \\
Total interface module (dry), kg & 196 & 190 & 192 & 192 \\
\hline Total dry mass, kg & 1428 & 1277 & 1335 & 1333 \\
\hline Propellant, kg & 3800 & 3394 & 3220 & 3001 \\
Tankage, kg & 380 & 339 & 322 & 300 \\
Tankage structure, kg & 167 & 149 & 142 & 132 \\
\hline Total propulsion system mass, kg & 5775 & 5159 & 5019 & 4766 \\
\hline
\end{tabular}


TABLE VI. - Concluded.

(c) Other mission scenarios, Xenon

\begin{tabular}{|c|c|c|c|c|c|c|}
\hline Mission scenario & $\begin{array}{l}\text { GEO } \\
\text { spiral }\end{array}$ & $\begin{array}{l}\text { Lunar } \\
\text { spiral }\end{array}$ & $\begin{array}{c}\text { NSO } \\
\text { vescape }\end{array}$ & $\begin{array}{c}\text { GED } \\
\text { vescape }\end{array}$ & $\begin{array}{l}\text { Lunar } \\
\text { vescape }\end{array}$ & $\begin{array}{l}\text { Lunar } \\
\text { spiral }\end{array}$ \\
\hline $\begin{array}{l}\text { Propel lant } \\
\text { Isp, sec } \\
\text { Total power, kw } \\
\text { Number of thrusters }\end{array}$ & $\begin{array}{r}\text { Xenon } \\
5294 \\
300 \\
5\end{array}$ & $\begin{array}{r}\text { Xenon } \\
5294 \\
300 \\
5\end{array}$ & $\begin{array}{r}\text { Xenon } \\
5294 \\
300 \\
5\end{array}$ & $\begin{array}{r}\text { Xenon } \\
5294 \\
300 \\
5\end{array}$ & $\begin{array}{r}\text { Xenon } \\
5294 \\
300 \\
5\end{array}$ & $\begin{array}{rl}\text { Xenon } \\
5 & 294 \\
3 & 000 \\
& 50\end{array}$ \\
\hline $\begin{array}{l}\text { Thruster/Gimbal, } \mathrm{kg} \\
\text { Thermal control, } \mathrm{kg} \\
\text { Power processor, } \mathrm{kg} \\
\text { Thruster structure, } \mathrm{kg} \\
\text { Total interface module (dry), } \mathrm{kg}\end{array}$ & $\begin{array}{r}137 \\
648 \\
475 \\
42 \\
199\end{array}$ & $\begin{array}{r}137 \\
648 \\
475 \\
42 \\
199\end{array}$ & $\begin{array}{r}137 \\
648 \\
475 \\
42 \\
199\end{array}$ & $\begin{array}{r}137 \\
648 \\
475 \\
42 \\
199\end{array}$ & $\begin{array}{r}137 \\
648 \\
475 \\
42 \\
199\end{array}$ & $\begin{array}{rl}1 & 367 \\
6 & 480 \\
4 & 749 \\
& 424 \\
1 & 889\end{array}$ \\
\hline Total dry mass, kg & 1501 & 1501 & 1501 & 1501 & 1501 & 14909 \\
\hline $\begin{array}{l}\text { Propellant, } \mathrm{kg} \\
\text { Tankage, } \mathrm{kg} \\
\text { Tankage structure, } \mathrm{kg}\end{array}$ & $\begin{array}{r}3562 \\
356 \\
157\end{array}$ & $\begin{array}{r}3365 \\
337 \\
148\end{array}$ & $\begin{array}{r}2709 \\
271 \\
119\end{array}$ & $\begin{array}{r}2644 \\
264 \\
116\end{array}$ & $\begin{array}{r}2463 \\
246 \\
108\end{array}$ & $\begin{array}{r}19965 \\
1997 \\
878\end{array}$ \\
\hline Total propulsion system mass, $\mathrm{kg}$ & 5576 & 5351 & 4600 & 4525 & 4318 & 37749 \\
\hline
\end{tabular}

(d) Other mission scenarios, Argon

\begin{tabular}{|c|c|c|c|c|c|c|}
\hline Mission scenario & $\begin{array}{l}\text { GEO } \\
\text { spiral }\end{array}$ & $\begin{array}{l}\text { Lunar } \\
\text { spiral }\end{array}$ & $\begin{array}{c}\text { NSO } \\
\text { vescape }\end{array}$ & $\begin{array}{c}\text { GEO } \\
\text { vescape }\end{array}$ & $\begin{array}{l}\text { Lunar } \\
\text { vescape }\end{array}$ & $\begin{array}{l}\text { Lunar } \\
\text { spiral }\end{array}$ \\
\hline $\begin{array}{l}\text { Propellant } \\
\text { Isp, sec } \\
\text { Total power, kW } \\
\text { Number of thrusters }\end{array}$ & $\begin{array}{r}\text { Argon } \\
9591 \\
300 \\
3\end{array}$ & $\begin{array}{r}\text { Argon } \\
9591 \\
300 \\
3\end{array}$ & $\begin{array}{r}\text { Argon } \\
9591 \\
300 \\
3\end{array}$ & $\begin{array}{r}\text { Argon } \\
9591 \\
300 \\
3\end{array}$ & $\begin{array}{r}\text { Argon } \\
9591 \\
300 \\
3\end{array}$ & $\begin{array}{rr}\text { Argon } \\
9 & 591 \\
3 & 000 \\
& 30\end{array}$ \\
\hline $\begin{array}{l}\text { Thruster/Gimbal, } \mathrm{kg} \\
\text { Thermal control, kg } \\
\text { Power processor, kg } \\
\text { Thruster structure, } \mathrm{kg} \\
\text { Total interface module (dry), } \mathrm{kg}\end{array}$ & $\begin{array}{r}82 \\
648 \\
386 \\
25 \\
192\end{array}$ & $\begin{array}{r}82 \\
648 \\
386 \\
25 \\
192\end{array}$ & $\begin{array}{r}82 \\
648 \\
386 \\
25 \\
192\end{array}$ & $\begin{array}{r}82 \\
648 \\
386 \\
25 \\
192\end{array}$ & $\begin{array}{r}82 \\
648 \\
386 \\
25 \\
192\end{array}$ & $\begin{array}{ll} & 820 \\
6 & 480 \\
3 & 864 \\
& 254 \\
1 & 820\end{array}$ \\
\hline Total dry mass, kg & 1333 & 1333 & 1333 & 1333 & 1333 & 13238 \\
\hline $\begin{array}{l}\text { Propellant, } \mathrm{kg} \\
\text { Tankage, } \mathrm{kg} \\
\text { Tankage structure, } \mathrm{kg}\end{array}$ & $\begin{array}{r}1970 \\
197 \\
87\end{array}$ & $\begin{array}{r}1211 \\
121 \\
53\end{array}$ & $\begin{array}{r}1529 \\
153 \\
67\end{array}$ & $\begin{array}{r}1514 \\
151 \\
67\end{array}$ & $\begin{array}{r}1393 \\
139 \\
61\end{array}$ & $\begin{array}{r}13346 \\
1335 \\
\\
\quad 587\end{array}$ \\
\hline Total propulsion system mass, kg & 3587 & 2718 & 3082 & 3065 & 2926 & 28506 \\
\hline
\end{tabular}


TABLE VII. - MISSION PARAMETERS

(a) Nuclear start orbit spiral, Xenon, $300 \mathrm{~kW}$

\begin{tabular}{|c|c|c|c|c|}
\hline Mission scenario & $\begin{array}{l}\text { NSO } \\
\text { spiral }\end{array}$ & $\begin{array}{l}\text { NSO } \\
\text { spiral }\end{array}$ & $\begin{array}{l}\text { NSO } \\
\text { spiral }\end{array}$ & $\begin{array}{l}\text { NSO } \\
\text { splral }\end{array}$ \\
\hline $\begin{array}{l}\text { Propellant } \\
\text { Isp, sec } \\
\text { Total power, } \mathrm{kw} \\
\text { Number of thrusters } \\
\text { Initial thrust/weight } \\
\text { Delta } \mathrm{v}, \mathrm{m} / \mathrm{s} \\
\text { Time of spiral, days } \\
\text { Time of thrust, days } \\
\text { Total mission time, days }\end{array}$ & $\begin{array}{rr}\text { Xenon } \\
4 & 138 \\
300 \\
7 \\
4.39 & E-5 \\
12 & 919 \\
174 \\
298 \\
467\end{array}$ & 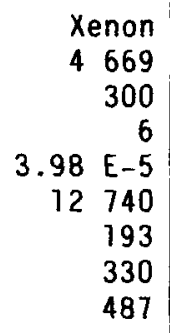 & $\begin{array}{rr}\text { Xenon } \\
4 & 991 \\
300 \\
5 \\
3.75 & E-5 \\
12 & 601 \\
205 \\
350 \\
499\end{array}$ & $\begin{array}{rr} & \text { Xenon } \\
5 & 294 \\
& 300 \\
& 5 \\
3.57 & E-5 \\
12 & 697 \\
& 216 \\
& 372 \\
510\end{array}$ \\
\hline $\begin{array}{l}\text { Initial mass, } \mathrm{kg} \\
\text { Power source mass, } \mathrm{kg} \\
\text { Contingency, } \mathrm{kg} \\
\text { Propulsion system mass, } \mathrm{kg}\end{array}$ & $\begin{array}{rr}23 & 180 \\
7 & 200 \\
1 & 000 \\
9 & 312\end{array}$ & $\begin{array}{rr}23 & 180 \\
7 & 200 \\
1 & 000 \\
8 & 399\end{array}$ & $\begin{array}{rr}23 & 180 \\
7 & 200 \\
1 & 000 \\
7 & 873\end{array}$ & $\begin{array}{rr}23 & 180 \\
7 & 200 \\
1 & 000 \\
7 & 588\end{array}$ \\
\hline Payload mass, $\mathrm{kg}$ & 5668 & 6581 & 7107 & 7392 \\
\hline
\end{tabular}

(b) Nuclear start orbit spiral, Argon, $300 \mathrm{~kW}$

\begin{tabular}{|c|c|c|c|c|}
\hline Mission scenario & $\begin{array}{c}\text { NSO } \\
\text { spiral }\end{array}$ & $\begin{array}{c}\text { NSO } \\
\text { spiral }\end{array}$ & $\begin{array}{l}\text { NSO } \\
\text { spiral }\end{array}$ & $\begin{array}{c}\text { NSO } \\
\text { spiral }\end{array}$ \\
\hline $\begin{array}{l}\text { Propellant } \\
\text { Isp, sec } \\
\text { Total power, kw } \\
\text { Number of thrusters } \\
\text { Initial thrust/weight } \\
\text { Delta } \mathrm{V}, \mathrm{m} / \mathrm{s} \\
\text { Time of spiral, days } \\
\text { Time of thrust, days } \\
\text { Total mission time, days }\end{array}$ & $\begin{array}{rr}\text { Argon } \\
7 & 498 \\
& 300 \\
& 4 \\
2.41 & E-5 \\
12 & 410 \\
325 \\
559 \\
663\end{array}$ & 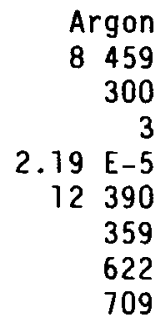 & 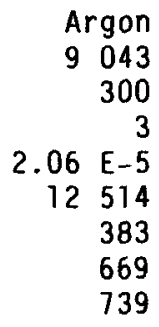 & $\begin{array}{rr}\text { Argon } \\
9 & 591 \\
& 300 \\
& 3 \\
1.96 & E-5 \\
12 & 306 \\
402 \\
695 \\
770\end{array}$ \\
\hline $\begin{array}{l}\text { Initial mass, } \mathrm{kg} \\
\text { Power source mass, } \mathrm{kg} \\
\text { Contingency, } \mathrm{kg} \\
\text { Propulsion system mass, } \mathrm{kg}\end{array}$ & $\begin{array}{rr}23 & 180 \\
7 & 200 \\
1 & 000 \\
5 & 775\end{array}$ & $\begin{array}{rr}23 & 180 \\
7 & 200 \\
1 & 000 \\
5 & 159\end{array}$ & $\begin{array}{rr}23 & 180 \\
7 & 200 \\
1 & 000 \\
5 & 019\end{array}$ & $\begin{array}{rr}23 & 180 \\
7 & 200 \\
1 & 000 \\
4 & 766\end{array}$ \\
\hline Payload mass, kg & 9205 & 9821 & 9961 & $10 \quad 214$ \\
\hline
\end{tabular}


TABLE VII. - Concluded.

(c) Other mission scenarios, Xenon

\begin{tabular}{|c|c|c|c|c|c|c|}
\hline Mission scenarto & $\begin{array}{l}\text { GEO } \\
\text { spiral }\end{array}$ & $\begin{array}{l}\text { Lunar } \\
\text { spiral }\end{array}$ & $\begin{array}{c}\text { NSO } \\
\text { vescape }\end{array}$ & $\begin{array}{c}\text { GEO } \\
\text { vescape }\end{array}$ & $\begin{array}{l}\text { Lunar } \\
\text { vescape }\end{array}$ & $\begin{array}{l}\text { Lunar } \\
\text { sptral }\end{array}$ \\
\hline $\begin{array}{l}\text { Propellant } \\
\text { Isp, sec } \\
\text { Total power, } \mathrm{kw} \\
\text { Number of thrusters } \\
\text { Initial thrust/weight } \\
\text { Delta } \mathrm{V}, \mathrm{m} / \mathrm{s} \\
\text { Time of spiral, days } \\
\text { Time of thrust, days } \\
\text { Total mission time, days }\end{array}$ & $\begin{array}{rr}\text { Xenon } \\
5 & 294 \\
& 300 \\
& 5 \\
3.57 & E-5 \\
8 & 143 \\
83 \\
249 \\
289 \\
389\end{array}$ & 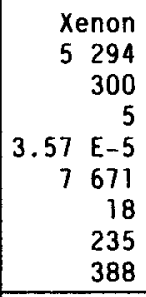 & 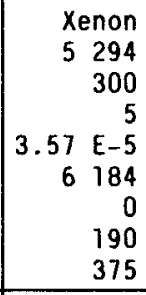 & 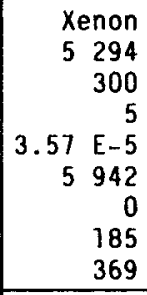 & $\begin{array}{rr}\text { Xenon } \\
5 & 294 \\
300 \\
5 \\
57 \\
5-5 \\
5 \quad 501 \\
0 \\
172 \\
344 \\
\end{array}$ & $\begin{array}{r}\text { Xenon } \\
5294 \\
3000 \\
50 \\
5.52 \quad E-5 \\
6 \quad 988 \\
15 \\
140 \\
356 \\
\end{array}$ \\
\hline $\begin{array}{l}\text { Initial mass, } \mathrm{kg} \\
\text { Power source mass, } \mathrm{kg} \\
\text { Contingency, kg } \\
\text { Propulsion system mass, } \mathrm{kg}\end{array}$ & $\begin{array}{rr}23 & 180 \\
7 & 200 \\
1 & 000 \\
5 & 576\end{array}$ & $\begin{array}{rr}23 & 180 \\
7 & 200 \\
1 & 000 \\
5 & 351\end{array}$ & $\begin{array}{rr}23 & 180 \\
7 & 200 \\
1 & 000 \\
4 & 600\end{array}$ & $\begin{array}{rr}23 & 180 \\
7 & 200 \\
1 & 000 \\
4 & 525\end{array}$ & $\begin{array}{rr}23 & 180 \\
7 & 200 \\
7 & 000 \\
4 & 318\end{array}$ & $\begin{array}{rl}150 & 000 \\
30 & 000 \\
10 & 000 \\
37 & 749\end{array}$ \\
\hline Payload mass, kg & 9404 & 9629 & 10380 & 10455 & 10662 & 72251 \\
\hline
\end{tabular}

(d) Other mission scenarios, Argon

\begin{tabular}{|c|c|c|c|c|c|c|}
\hline Mission scenario & $\begin{array}{l}\text { GEO } \\
\text { spiral }\end{array}$ & $\begin{array}{l}\text { Lunar } \\
\text { spiral }\end{array}$ & $\begin{array}{c}\text { NSO } \\
\text { vescape }\end{array}$ & $\begin{array}{c}\text { GEO } \\
\text { vescape }\end{array}$ & $\begin{array}{l}\text { Lunar } \\
\text { vescape }\end{array}$ & $\begin{array}{l}\text { Lunar } \\
\text { spiral }\end{array}$ \\
\hline $\begin{array}{l}\text { Propel lant } \\
\text { Isp, sec } \\
\text { Total power, } \mathrm{kw} \\
\text { Number of thrusters } \\
\text { Initial thrust/weight } \\
\text { Delta } \mathrm{V}, \mathrm{m} / \mathrm{s} \\
\text { Time of spiral, days } \\
\text { Time of thrust, days } \\
\text { Total mission time, days }\end{array}$ & $\begin{array}{r}\text { Argon } \\
9591 \\
300 \\
3 \\
3.96 \quad E-5 \\
7892 \\
149 \\
456 \\
524\end{array}$ & $\begin{array}{r}\text { Argon } \\
9591 \\
300 \\
3 \\
1.96 \quad E-5 \\
5844 \\
25 \\
343 \\
400\end{array}$ & $\begin{array}{rr}\text { Argon } \\
9591 \\
300 \\
3 \\
3 \\
1.96 \text { E-5 } \\
6071 \\
0 \\
354 \\
431\end{array}$ & $\begin{array}{rr}\text { Argon } \\
9591 \\
300 \\
3 \\
3.96 \text { E-5 } \\
6012 \\
0 \\
351 \\
419\end{array}$ & $\begin{array}{r}\text { Argon } \\
9591 \\
300 \\
3 \\
1.96 \quad E-5 \\
5514 \\
0 \\
322 \\
400\end{array}$ & $\begin{array}{rr}\text { Argon } \\
9 & 591 \\
3 & 000 \\
& 30 \\
3.03 \quad E-5 \\
8 \quad 286 \\
20 \\
309 \\
413\end{array}$ \\
\hline $\begin{array}{l}\text { Initial mass, } \mathrm{kg} \\
\text { Power source mass, } \mathrm{kg} \\
\text { Contingency, } \mathrm{kg} \\
\text { Propulsion system mass, } \mathrm{kg}\end{array}$ & $\begin{array}{rr}23 & 180 \\
7 & 200 \\
1 & 000 \\
3 & 587\end{array}$ & $\begin{array}{rr}23 & 180 \\
7 & 200 \\
1 & 000 \\
2 & 718\end{array}$ & $\begin{array}{rr}23 & 180 \\
7 & 200 \\
1 & 000 \\
3 & 082\end{array}$ & $\begin{array}{rr}23 & 180 \\
7 & 200 \\
1 & 000 \\
3 & 065\end{array}$ & $\begin{array}{rr}23 & 180 \\
7 & 200 \\
1 & 000 \\
2 & 926\end{array}$ & $\begin{array}{rr}150 & 000 \\
30 & 000 \\
10 & 000 \\
28 & 506\end{array}$ \\
\hline Payload mass, $\mathrm{kg}$ & 11393 & 12262 & 11898 & 11915 & 12054 & 81494 \\
\hline
\end{tabular}


TABLE VIII. - DETAILED TRAJECTORY FOR NSO SPIRAL, XENON,

$300 \mathrm{~kW}$, Isp $=5294 \mathrm{sec}$

\begin{tabular}{|c|c|c|c|c|c|c|c|}
\hline $\begin{array}{l}\text { Time, } \\
\text { days }\end{array}$ & $\underset{\text { m }}{\text { Radius, }}$ & $\begin{array}{c}\text { velocity, } \\
\mathrm{m} / \mathrm{s}\end{array}$ & $\begin{array}{c}\text { Path angle, } \\
\text { deg }\end{array}$ & $\begin{array}{l}\text { Revs. } \\
\text { about } \\
\text { Earth }\end{array}$ & \multicolumn{2}{|c|}{ Eccentricity } & $\begin{array}{c}\text { Vehicle } \\
\text { mass, } \\
\text { kg }\end{array}$ \\
\hline $\begin{array}{r}0 \\
10 \\
20 \\
30 \\
40 \\
50 \\
60 \\
70 \\
80 \\
90 \\
100 \\
110 \\
120 \\
130 \\
140 \\
150 \\
160 \\
170 \\
180 \\
190 \\
200 \\
210 \\
216.34\end{array}$ & $\begin{array}{l}7.178 \mathrm{E} 6 \\
7.789 \\
8.487 \\
9.292 \\
1.022 \mathrm{E} 7 \\
1.131 \\
1.260 \\
1.413 \\
1.597 \\
1.821 \\
2.098 \\
2.445 \\
2.891 \\
3.475 \\
4.261 \\
5.357 \\
6.949 \\
9.391 \\
1.342 \mathrm{E} 8 \\
2.065 \\
3.506 \\
6.296 \\
9.250\end{array}$ & $\begin{array}{ll}7 & 452 \\
7 & 154 \\
6 & 853 \\
6 & 549 \\
6 & 244 \\
5 & 936 \\
5 & 625 \\
5 & 312 \\
4 & 996 \\
4 & 679 \\
4 & 359 \\
4 & 038 \\
3 & 713 \\
3 & 387 \\
3 & 059 \\
2 & 728 \\
2 & 395 \\
2 & 061 \\
1 & 725 \\
1 & 400 \\
1 & 105 \\
& 963 \\
& 958\end{array}$ & $\begin{array}{c}0.000 \\
.0715 \\
.00235 \\
.00445 \\
.0118 \\
.0135 \\
.0129 \\
.0241 \\
.0281 \\
.0342 \\
.0483 \\
.0642 \\
.0923 \\
.130 \\
.201 \\
.315 \\
.542 \\
.978 \\
2.016 \\
4.727 \\
12.39 \\
27.32 \\
43.0\end{array}$ & $\begin{array}{r}0.00 \\
134.42 \\
252.98 \\
356.86 \\
447.21 \\
525.18 \\
591.86 \\
648.32 \\
695.60 \\
734.72 \\
766.61 \\
792.18 \\
812.29 \\
827.76 \\
839.34 \\
847.72 \\
853.54 \\
857.38 \\
859.73 \\
861.05 \\
861.70 \\
861.99 \\
863.00\end{array}$ & $\begin{array}{l}4.67 \\
2.017 \\
5.375 \\
8.361 \\
2.226 \\
2.486 \\
2.259 \\
4.220 \\
4.935 \\
5.987 \\
8.447 \\
1.123 \\
1.612 \\
2.263 \\
3.502 \\
5.499 \\
9.453 \\
1.707 \\
3.523 \\
8.368 \\
.226 \\
.617 \\
1.13\end{array}$ & $\begin{array}{l}E-5 \\
E-4 \\
E-5 \\
E-5 \\
E-4 \\
E-4 \\
E-4 \\
E-4 \\
E-4 \\
E-4 \\
E-4 \\
E-3 \\
E-3 \\
E-3 \\
E-3 \\
E-3 \\
E-3 \\
E-2 \\
E-2 \\
E-2\end{array}$ & $\begin{array}{ll}23 & 180 \\
23 & 045 \\
22 & 910 \\
22 & 774 \\
22 & 639 \\
22 & 504 \\
22 & 369 \\
22 & 233 \\
22 & 098 \\
21 & 963 \\
21 & 828 \\
21 & 693 \\
21 & 557 \\
21 & 422 \\
21 & 287 \\
21 & 152 \\
21 & 017 \\
20 & 881 \\
20 & 746 \\
20 & 611 \\
20 & 476 \\
20 & 340 \\
20 & 243\end{array}$ \\
\hline Switch & origin fror & Earth to & & $\begin{array}{c}\text { Central } \\
\text { travel } \\
\text { angle, } \\
\text { deg }\end{array}$ & & & \\
\hline $\begin{array}{l}216.34 \\
219.61 \\
222.99 \\
226.55 \\
230.59 \\
235.24 \\
241.26 \\
249.69 \\
262.53 \\
280.21 \\
282.01 \\
289.24 \\
312.06 \\
338.82 \\
372.36 \\
413.62 \\
419.84 \\
437.59 \\
493.84 \\
509.36\end{array}$ & $\begin{array}{l}1.510 \text { E11 } \\
1.508 \\
1.507 \\
1.505 \\
1.504 \\
1.502 \\
1.502 \\
1.504 \\
1.574 \\
1.546 \\
1.571 \\
1.571 \\
1.657 \\
1.781 \\
1.944 \\
2.120 \\
2.143 \\
2.197 \\
2.276 \\
2.278\end{array}$ & $\begin{array}{ll}30 & 654 \\
30 & 772 \\
30 & 871 \\
30 & 965 \\
31 & 076 \\
31 & 212 \\
31 & 392 \\
31 & 624 \\
31 & 872 \\
31 & 927 \\
31 & 912 \\
31 & 554 \\
30 & 135 \\
28 & 219 \\
25 & 911 \\
23 & 624 \\
23 & 344 \\
23 & 076 \\
23 & 656 \\
24 & 104\end{array}$ & $\begin{array}{c}-0.92 \\
-.98 \\
-.98 \\
-.90 \\
-.73 \\
-.44 \\
.0476 \\
.89 \\
2.49 \\
5.15 \\
5.44 \\
6.57 \\
9.48 \\
11.54 \\
12.15 \\
10.50 \\
10.07 \\
7.53 \\
1.04 \\
-.00167\end{array}$ & $\begin{array}{l}211.80 \\
215.09 \\
218.51 \\
222.13 \\
226.25 \\
231.02 \\
237.24 \\
245.98 \\
259.37 \\
277.61 \\
279.45 \\
286.69 \\
308.11 \\
330.25 \\
353.85 \\
378.17 \\
381.51 \\
390.78 \\
419.45 \\
427.51\end{array}$ & $\begin{array}{l}7.07 \\
7.80 \\
8.37 \\
8.88 \\
9.49 \\
.103 \\
.115 \\
.134 \\
.164 \\
.207 \\
.211 \\
.211 \\
.211 \\
.211 \\
.211 \\
.211 \\
.211 \\
.176 \\
4.44 \\
2.64\end{array}$ & $\begin{array}{l}E-2 \\
E-2 \\
E-2 \\
E-2 \\
E-2 \\
\\
\\
E-2 \\
E-3\end{array}$ & $\begin{array}{ll}20 & 243 \\
20 & 199 \\
20 & 153 \\
20 & 105 \\
20 & 050 \\
19 & 988 \\
19 & 906 \\
19 & 792 \\
19 & 619 \\
19 & 380 \\
19 & 355 \\
19 & 355 \\
19 & 355 \\
19 & 355 \\
19 & 355 \\
19 & 355 \\
19 & 355 \\
19 & 115 \\
18 & 355 \\
18 & 145\end{array}$ \\
\hline
\end{tabular}




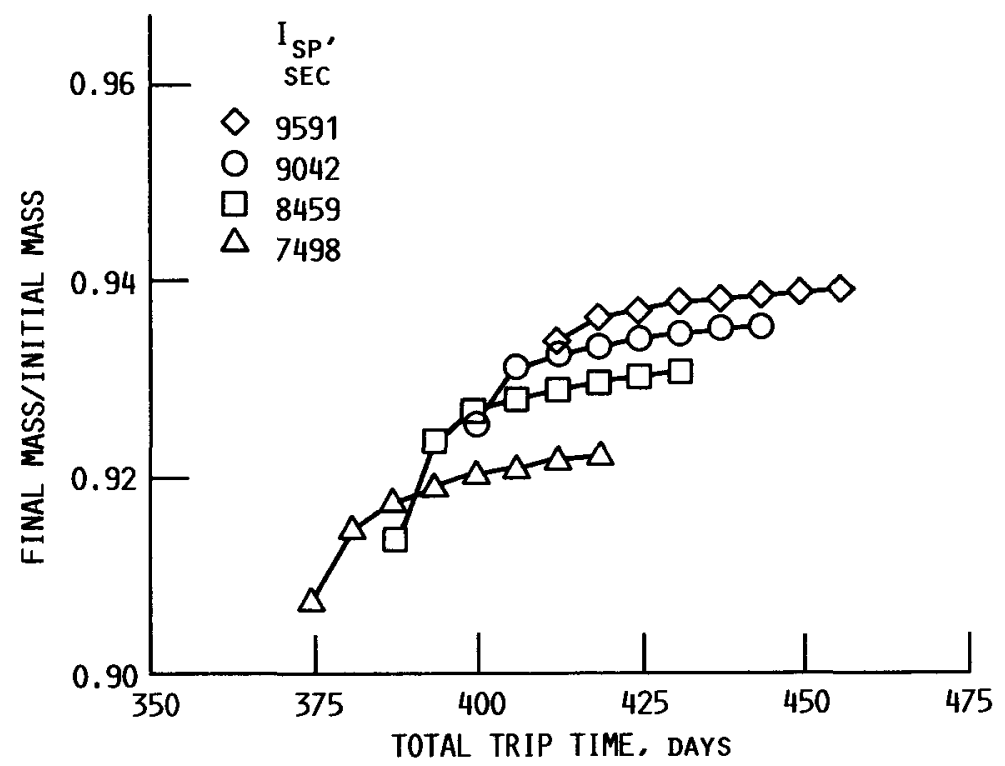

FIGURE 1. - EFFECT OF TRIP TIME ON FINAL MASS. INITIAL CONDITION: NSO WITH ESCAPE VELOCITY; POWER LEVEL: $300 \mathrm{~kW}$ : PROPELLANT: ARGON.

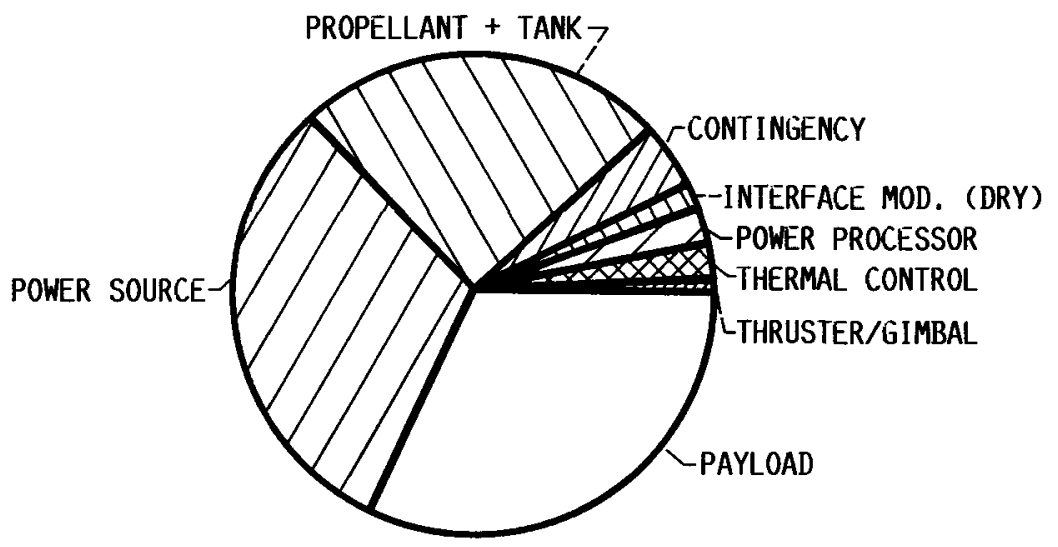

FIGURE 2. - BREAKDOWN OF SPACECRAFT MASSES FOR XE. INITIAL CONDITION: NSO WITH CIRCULAR VELOCITY: POWER LEVEL: $300 \mathrm{~kW}: \mathrm{I}_{\text {SP }}$ : 5294 SECONDS. 


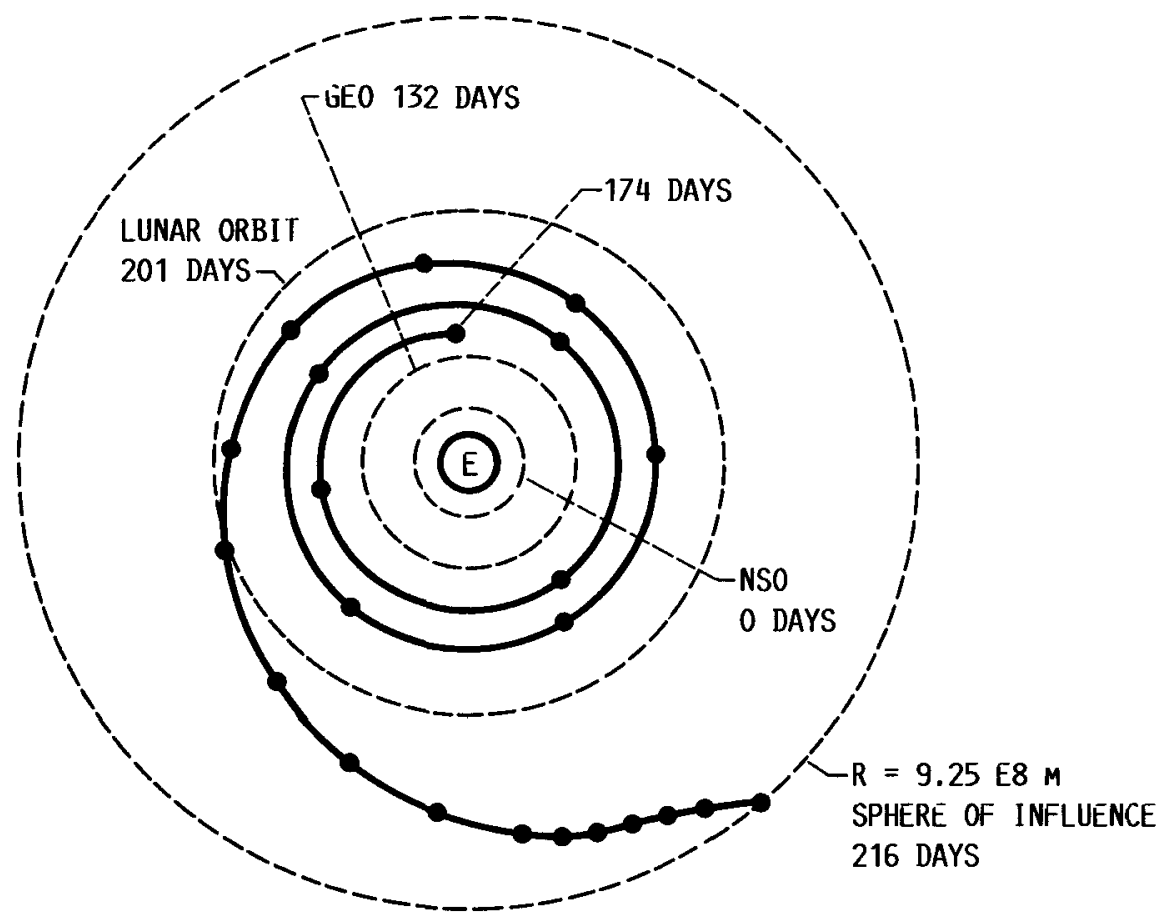

(A) GEOCENTRIC PHASE.

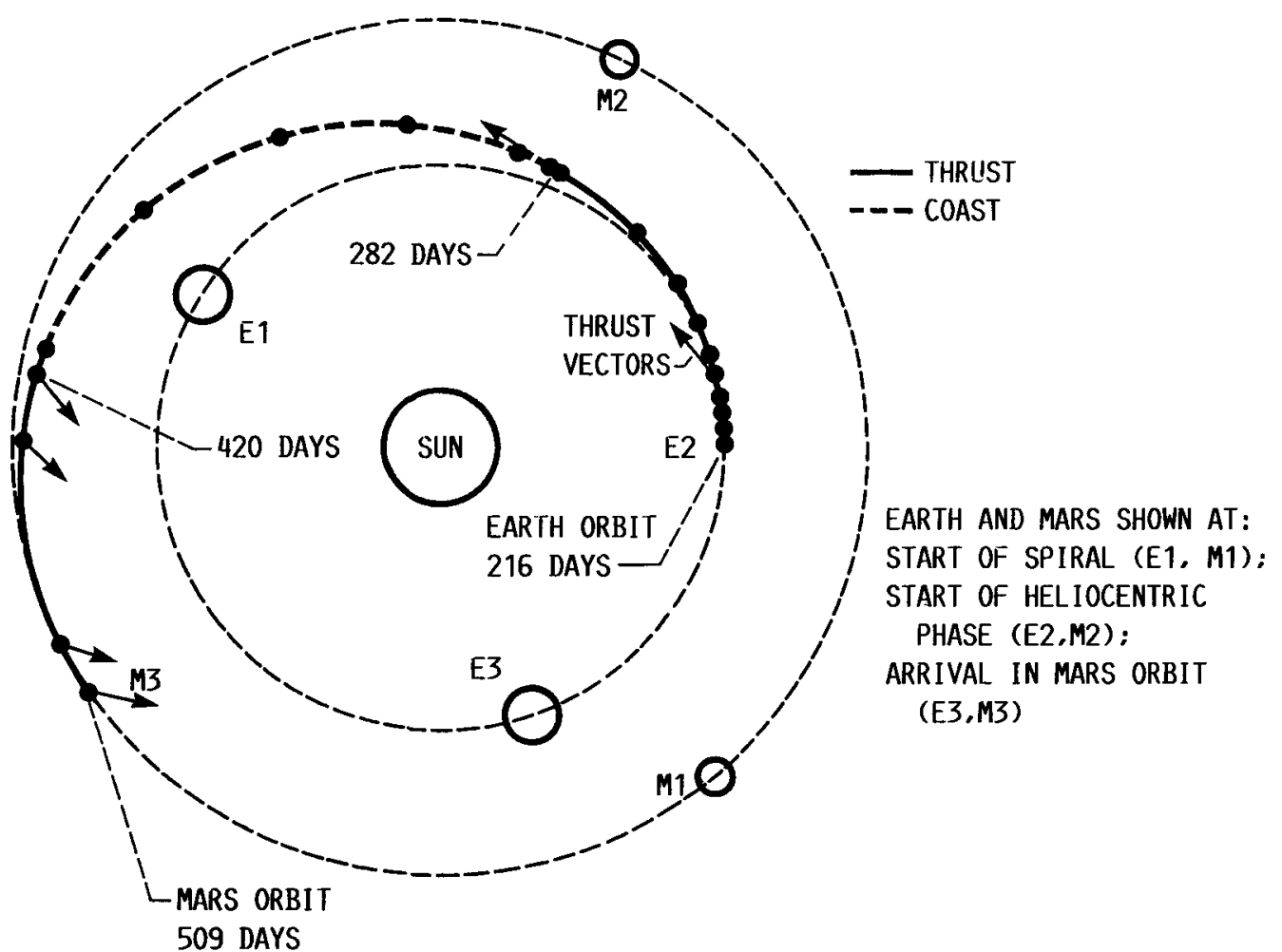

(B) HELIOCENTRIC PHASE.

FIGURE 3.- INITIAL CONDITION: NSO WITH CIRCULAR VELOCITY. XENON, I POWER $=300 \mathrm{~kW}$. 


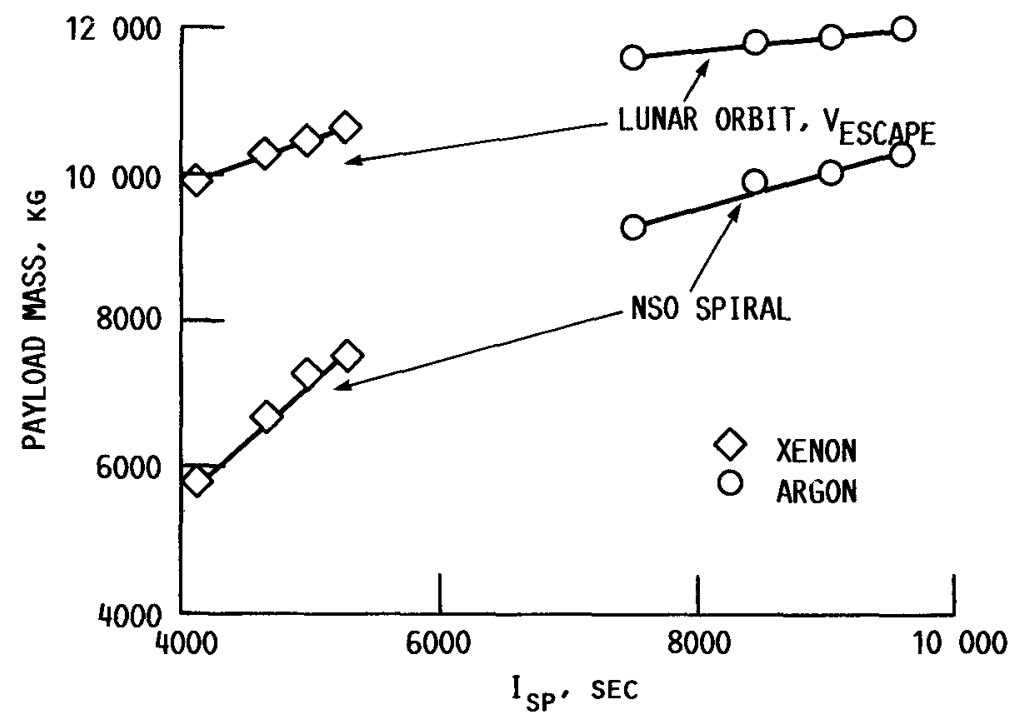

FIGURE 4. - EFFECT OF SPECIFIC IMPULSE ON PAYLOAD POWER LEVEL: $300 \mathrm{~kW}$.

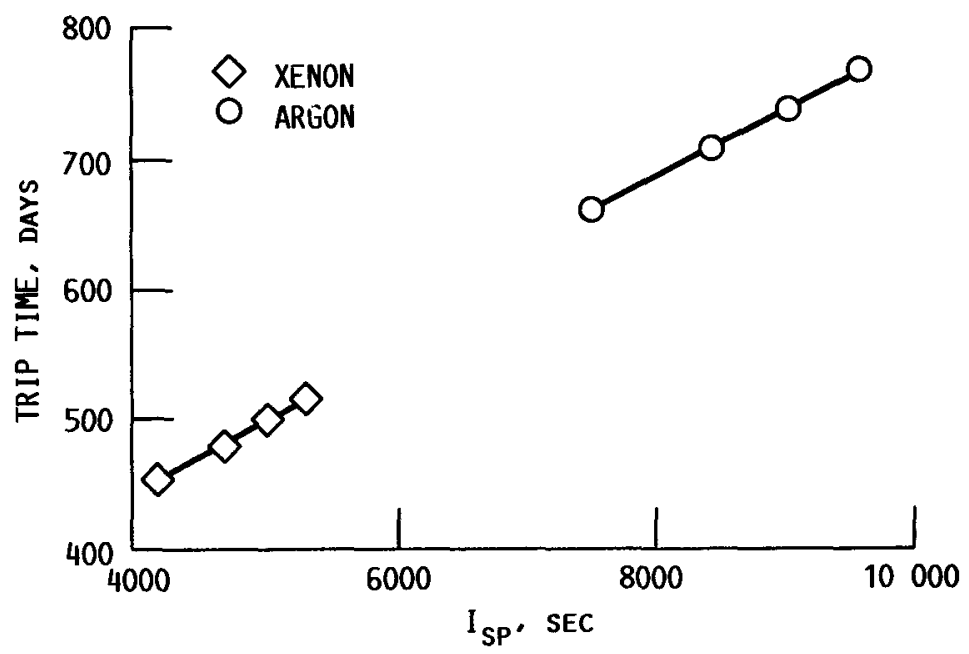

FIGURE 5.- EFFECT OF SPECIFIC IMPULSE ON TRIP TIME. INITIAL CONDITON: NSO WITH CIRCULAR VELOCITY; POWER LEVEL: $300 \mathrm{~kW}$. 


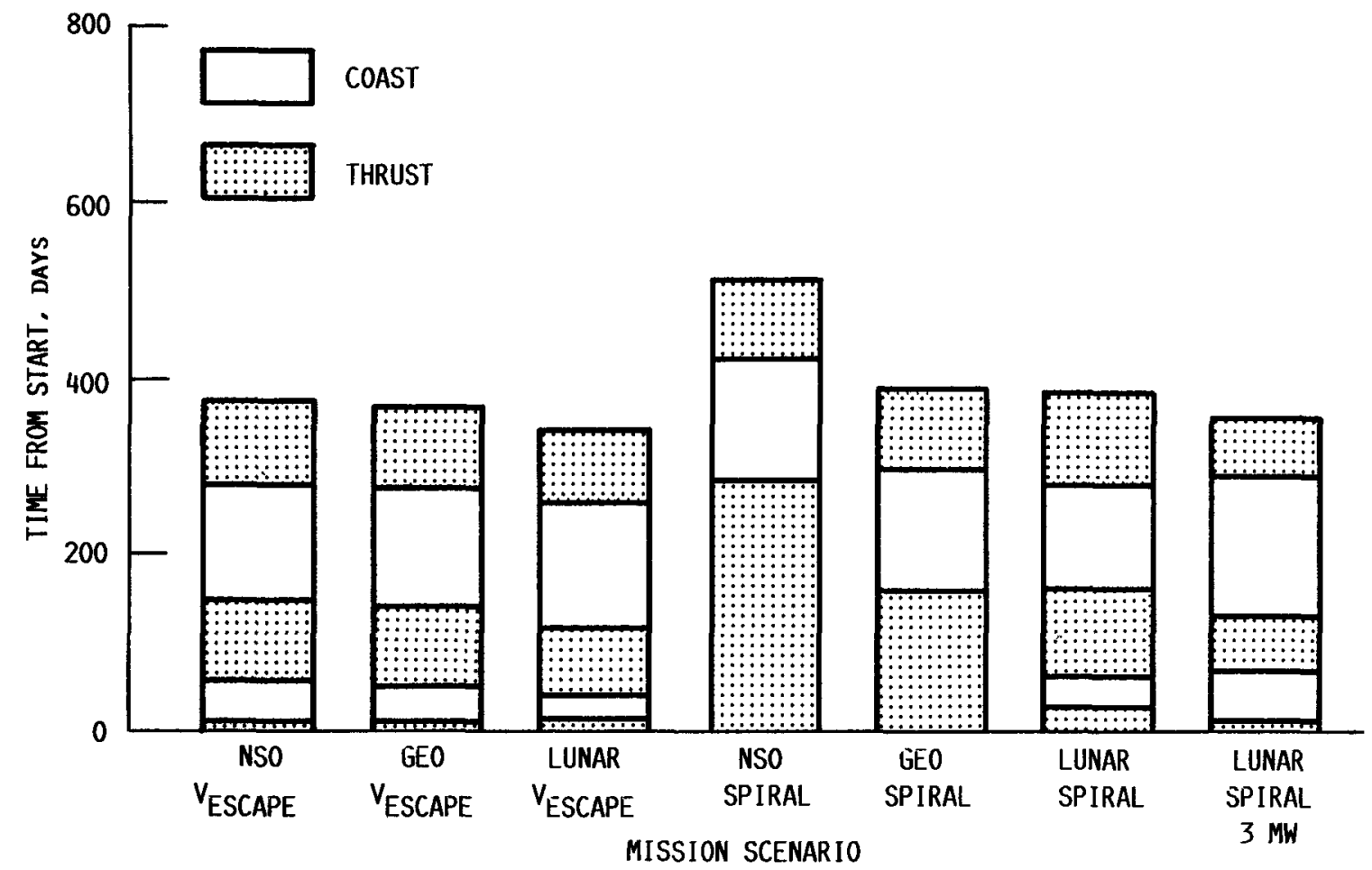

(A) XENON, $I_{S P}=5294 \mathrm{sEC}$.

FIGURE 6. - THRUST AND COAST TIME SUMMARY. POWER $=300 \mathrm{~kW}$ EXCEPT AS NOTED.

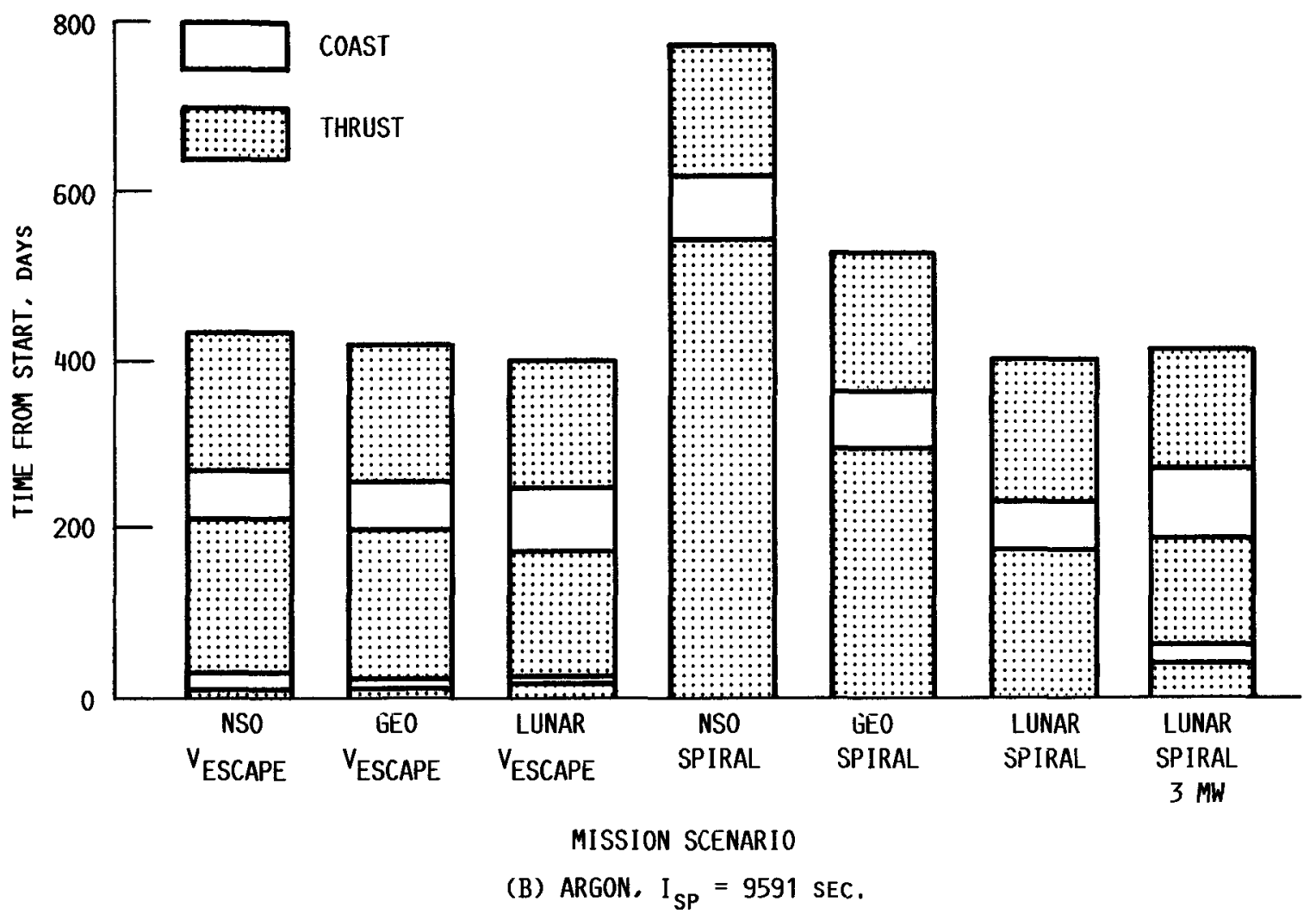

FIGURE 6. - CONCLUDED. 


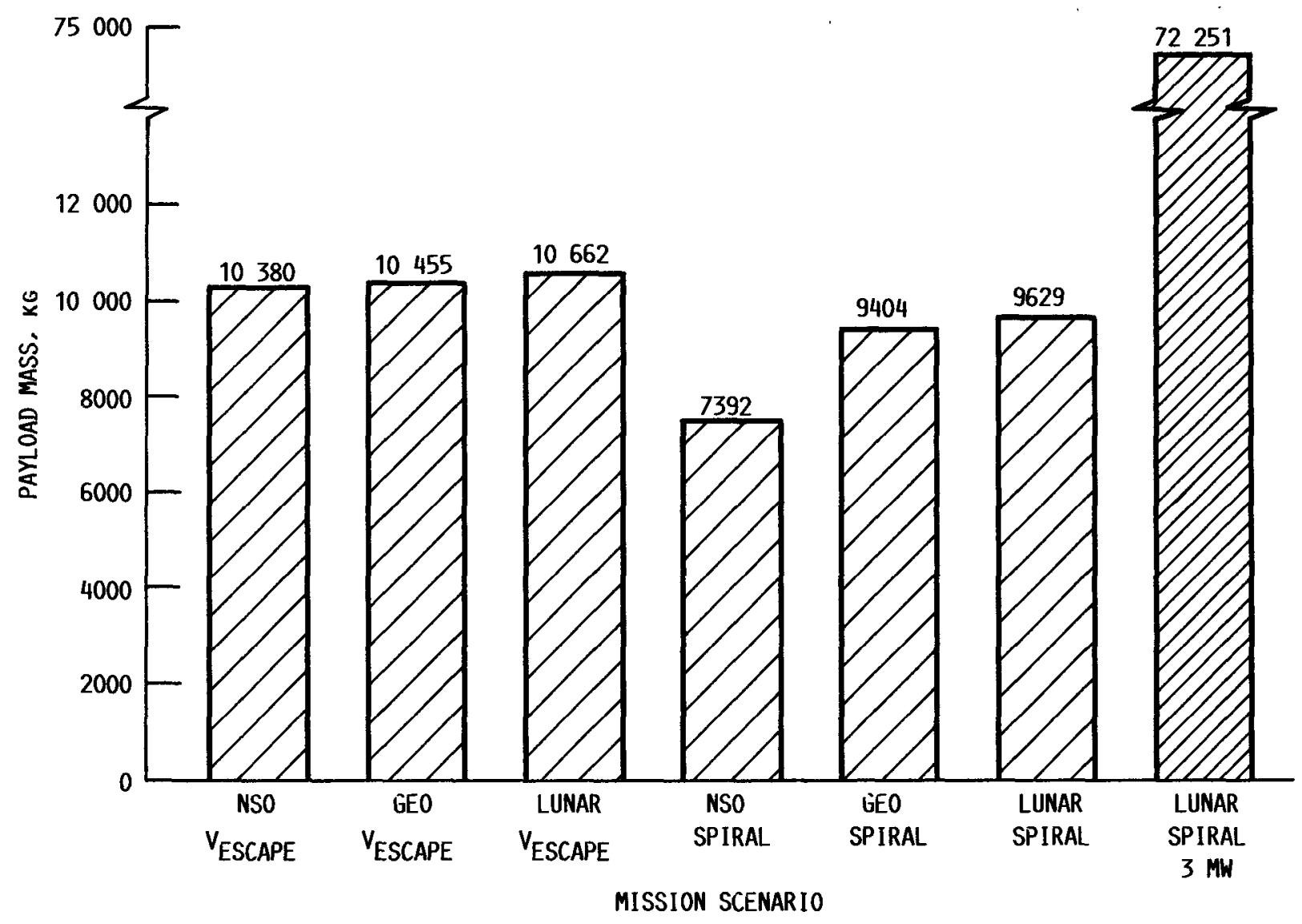

(A) XENON, I $I_{S P}=5294 \mathrm{sEC}$.

FIGURE 7. - PAYLOAD MASS SUMMARY. POWER $=300 \mathrm{~kW}$ EXCEPT AS NOTED. 


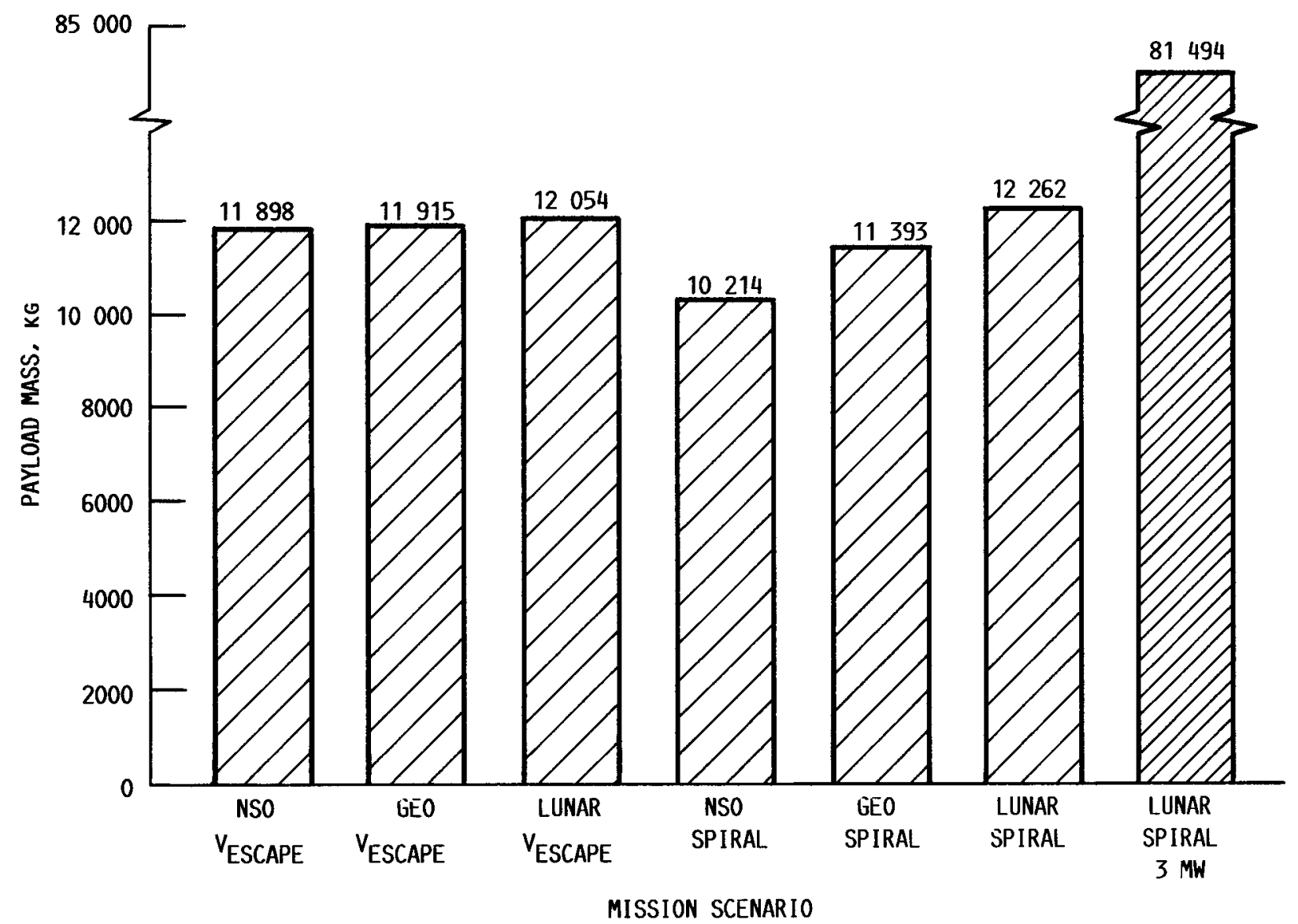

(B) ARGON, I SP $=9591 \mathrm{sEC}$.

FIGURE 7. - CONCLUDED. 


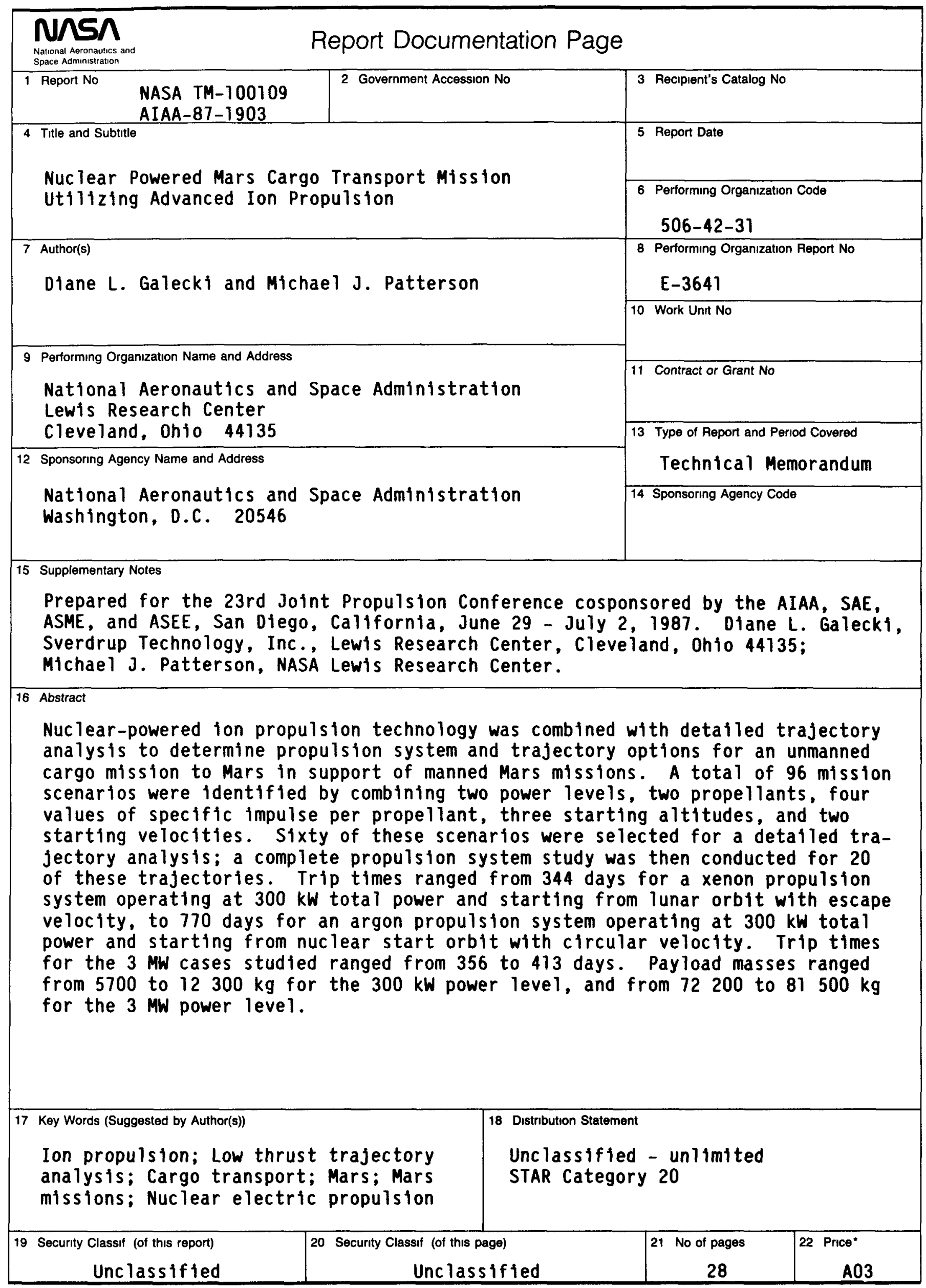

